\title{
Dispensas y matrimonios secretos en Buenos Aires e Hispanoamérica. Siglo XVIII
}

\author{
Nora SIEGRIST \\ Consejo Nacional de Investigaciones Científicas y Técnicas (CONICET) \\ Facultad de Ciencias Sociales Universidad Católica Argentina \\ nora.siegrist@gmail.com
}

Recepción: 21 de diciembre de 2015 / Revisión: 1 de marzo de 2016

Aceptación: 5 de abril de 2016 / Publicación: Diciembre de 2016

\section{RESUMEN}

Las partidas sacramentales y los matrimonios secretos -admitidos por la Iglesia Católica-revelan la existencia de casos desconocidos en la formación de la sociedad. Motivaciones de consanguinidad directa y concubinatos, disparidad de linaje, de religión, y falta de permisos de las autoridades a funcionarios de la administración de indias, y a militares para que pudieran casarse, son algunos ejemplos analizados para Buenos Aires e Hispanoamérica durante el siglo XVIII.

Palabras clave: Matrimonios secretos, Derecho Canónico, Buenos Aires, Hispanoamérica, siglo XVIII.

\section{Dispensations and Secret Marriages in Buenos Aires and Spanish America in the $18^{\text {th }}$ Century}

\begin{abstract}
Marriage certificates and secret marriages - recognized by the Catholic Church- reveal the existence of unknown cases in the formation of society. Dispensations granted for marriages of direct kinship or concubinage, differences of pedigree or religion, or for officials of the administration of the Indies or military men lacking marriage permits, are some of the examples analyzed herein for Buenos Aires and Spanish America in the 18th century.
\end{abstract}

Keywords: Secret marriages, Canon Law, Buenos Aires, Spanish America, $18^{\text {th }}$ Century.

SuMARio: 1. Introducción. 2. Legislación canónica con respecto a los matrimonios secretos. Novedades en lo histórico, socio-demográfico y cultural. 3. Antecedentes sobre la concreción de casamientos secretos en Hispanoamérica. 4. Acción del Virrey Loreto en orden a las nupcias realizadas en el Virreinato del Río de la Plata. 5. Casuística en Buenos Aires. Matrimonios de conciencia u ocultos de funcionarios, militares, viudas, comerciantes y otros pobladores. 6. Conclusiones. 7. Referencias bibliográficas. 


\section{INTRODUCCIÓN}

En esta ocasión, se hace referencia a la doctrina que se sostuvo durante la segunda mitad del siglo XVIII en relación con los matrimonios secretos, buscando ilustrar con ejemplos extraídos de la casuística algunos de las sustanciosas causas ocurridas. Cabe destacar, por lo demás, que se insiste en ciertos contenidos históricos correspondientes a esta centuria por constituir ejemplos que amplían los conocimientos que se tienen sobre este tipo de casamientos ocurridos en España y, especialmente, en Buenos Aires e Hispanoamérica. Se debe recordar que el Concilio de Trento (15451563) ordenó los impedimentos que afectaban la concreción de las nupcias, lo que produjo varios casos de los casamientos aquí tratados ${ }^{1}$.

Al respecto, Rípodas Ardanaz señaló que estos matrimonios, "amén de la ausencia de amonestaciones, se caracterizan por celebrarse ocultamente en presencia del párroco u otro sacerdote y dos testigos de confianza, y por ser registrados, a partir del breve Satis Vobis (1741) de Benedicto XIV, en un libro especial que se custodiaba en la Secretaría de Cámara de cada Obispado, requisito con el que no siempre parece haberse cumplido en América" 2 . De hecho, dicha autora consideró que no se habían concretado, salvo excepciones, por varios sondeos realizados a personas de competencia. Que no se sabía de la existencia de dichos libros en el territorio, según lo que preguntó a un colega conocedor de archivos de Córdoba del Tucumán, el Dr. Carlos Luque Colombres, que confirmó la falta de existencia de "libro alguno de matrimonios secretos llevados en dicha Diócesis durante la Colonia" 3 .

Vale acotar que en los tiempos en que Rípodas Ardanaz hizo sus apreciaciones, la falta de posibilidad de indagar en archivos digitales (como los que aportan las bases de los Mormones ${ }^{4}$ ) fundamentalmente para el territorio rioplatense hicieron, por entonces, totalmente imposible su búsqueda. Los enlaces secretos, justamente, resguardaban un contenido de esta misma original naturaleza: secreta, no comentada a la feligresía del común ni a la sociedad. No obstante, los estudios que aquella formalizó, aparte de sus afirmaciones compartidas con personas de su entorno, brindaron la primera pista de desposorios secretos que tuvieron lugar en el marco espacial rioplatense que se trata, lo que poco tiempo más tarde se constató para Córdoba ${ }^{5}$ del Tucumán y Mendoza, asimismo, en Cuyo y en Buenos Aires.

Debe expresarse que no se conocían las características básicas y peculiares que ya en España tenían este tipo de casamientos en su contexto general, las que fueron

1 PASTORA, 1848. III, p. 85, señala con referencia a los impedimentos dirimentes: 1. Error en cuanto a la persona, 2. Error en cuanto al estado, 3. Voto solemne, 4. El parentesco en ciertos grados, 5. El crimen, 6. La diferencia de religión, 7. La violencia. 8. Las órdenes sagradas. 9. Un primer matrimonio subsistente. 10. La honestidad pública. 11. La afinidad en determinados grados. 12. La impotencia. El Concilio de Trento sumó la clandestinidad y el rapto, si bien algunos canonistas indican también la locura.

2 RÍPODAS, 1977, p. 81.

3 Ibídem, p. 82 (46).

4 Iglesia de Jesucristo de los Santos de los Últimos Días (en adelante IJSUD). Familysearch.org, Mormones.

5 Siegrist - Ferreyra, 2012. 
analizadas, en relación a determinados comerciantes, en una destacada investigación de P. Fernández Pérez ${ }^{6}$.

Por su lado, en una ponencia pronunciada en la Facultad de Derecho Canónico de la Universidad de Navarra el 18 de septiembre de 1996, el Prof. J. Ferrer Ortiz reveló sobre los matrimonios secretos y las circunstancias que existían más de los que normalmente se consideraban. Igualmente, sobre los cánones 1130-1131 que reglaban su constitución.

Cabe agregar que en el lento acopio de antecedentes, hubo resultados concretos, así en la Introducción de José M. Pico al libro de C. Jaúregui Rueda, que transcribió los enlaces de los habitantes de la ciudad porteña entre 1747-1823, quien sostuvo:

Corresponde señalar también el carácter secreto de algunos matrimonios celebrados en la Catedral de Buenos Aires cuyas constancias fueron volcadas, a pedido de los contrayentes, en los libros de casamientos comunes correspondientes a los años 17471823. Este tipo de matrimonios se bendecía en América ocultamente, en presencia de un sacerdote y dos testigos de confianza y su partida se anotaba en los mencionados libros con el fin de que no pudiese probarse su existencia en perjuicio de quienes lo habían contraído. A partir del breve "Satis vobis" de Benedicto XIV, en 1741, fueron registrados en un tomo especial que se mantenía en la Secretaría de Cámara de cada Obispado $^{8}$.

Y los testimonios que tanto Jáuregui como Pico encontraron para Buenos Aires, se dejan ver en el párrafo textual:

Entre la importante documentación que leeremos (...) debemos señalar la partida 6492, pues echa luz sobre este tema. Por decreto del 21 de noviembre de 1803 se ordenó intercalar en el libro de casamientos comunes de la Catedral metropolitana dicha partida, correspondiente a los esponsales de don Juan Justo Marchan y García con doña María Pérez de la Mata Ruiz y Zamudio que comienza con esta nota: 10-6-1774: Casamiento secreto en casa de la contrayente.

Y finaliza con la siguiente leyenda:

Anotado a pedido de la contrayente, ya viuda, por haberse perdido el libro o cuaderno en que asentaba los matrimonios secretos el Sr. Magistral Dn. Juan Baltazar Maciel como Provisor y Gobernador de este Obispado, que los había casado?

De manera que salta a la vista que hubo una pérdida de un libro, o más, de matrimonios secretos, aparte que los que se registraron en este carácter fueron anotados en los libros de casamientos comunes antes de esa fecha de 1803.

Varios enlaces de los que se tratan constan en los libros de la Iglesia de La Merced. Se concretaron por causas que la Iglesia Católica estimó muy graves y/o por motivos

6 FERnÁNDEZ PÉREZ, 1997.

7 FERRER, 1997.

8 Pico, 1989; JÁuregui, 1989, p. 8.

9 Ibídem. 
que los interesados no podían soslayar en el siglo, como fueron las faltas de permisos del Rey o de las autoridades militares para que sus oficiales materializaran sus matrimonios en el tiempo deseado; por diferencias de religión de los contrayentes; por los comerciantes que habían firmado contratos con los que les encomendaban sus mercancías y/o caudales, pero lo habían realizado siendo célibes. Existía real temor de que estos perdieran la vida en naufragios o por las eventualidades de la vida; si eran casados podían existir reclamos de bienes gananciales de las viudas. A ello se agregó lo indicado en textos jurídicos que deben repetirse necesariamente:

La viuda que, si contrae segundas nupcias, pierde la tutela sobre sus hijos o queda inhabilitada para ejercer el comercio, con grave perjuicio para el mantenimiento y educación de la prole ${ }^{10}$.

Se agregaron las cuestiones de consanguinidad por impedimentos dirimentes o impedientes no dispensados; por concubinatos de larga data e hijos de por medio sin que la sociedad supiera que la pareja no había recibido el sacramento matrimonial; por diferencias de linajes notorios; en fin, las cuestiones fueron de diferente tenor.

Si se vuelve al relato de los desposorios secretos que no se encuentran anotados en los libros de matrimonios comunes, el citado J. M. Pico, buscó por años el acta de casamiento de sus antepasados. Este investigador consumió años de su vida sin poder hallarla ${ }^{11}$ hasta que, al fin, pudo conocer que tales nupcias se concertaron en la centuria decimoctava. El motivo de haberlas mantenido ocultas fueron, en este caso, las diferencias religiosas del contrayente, por lo que el casamiento se anotó de forma diferente a los matrimonios del común.

La consulta bibliográfica en otros espacios europeos y americanos, brindó novedosos datos, como los que hacen referencia a lo aquí tratado. Pueden señalarse una serie de peculiaridades en la concertación de estas bodas que no surgieron de la nada ya que respondieron a causas que la Iglesia no podía dispensar de la forma habitual.

Dougnac Rodríguez, en el Manual del Esquema del Derecho de Familia India$n o^{12}$, dice que hubo diferentes tipos de casamientos, como textualmente se recrean:

1. El legítimo, celebrado con el solo consentimiento natural, conforme a las leyes de cada comunidad y al derecho natural (dentro del cual se consideraba el de los infieles);

2. Rato, el contraído entre fieles con los requisitos propios del sacramento, pero sin que se hubiera producido cópula conyugal;

3. Consumado, que era el perfeccionado por la unión carnal, per copulam aptam ad generationem;

4. Putativo, al que se suponía verdadero por haberse contraído de acuerdo a las normas de la Iglesia y con buena fe de parte, por lo menos, de una de los contra-

\footnotetext{
10 Ferrer, 1997, p. 162.

11 Pico, 1991, pp. 167-202.

12 Dougnac, 2003, pp. 76-77.
} 
yentes, pero que, en realidad adolecía de nulidad por causa de algún impedimento dirimente. Los hijos habidos de tal matrimonio eran considerados legítimos;

5. Verdadero, el que se contrae entre personas que no se hallan ligadas con algún impedimento dirimente; $\mathrm{y}$

6. Presunto, el que presumía el derecho en razón del acto carnal ejecutado después de los esponsales aunque éstos hubieran sido condicionales y no se haya verificado la condición. Sólo era válido en los lugares donde no se hubiera aceptado el Concilio de Trento o publicado el decreto que declaraba nulos o írritos los matrimonios clandestinos;

7. Secreto, oculto o de conciencia, el que se celebraba escondidamente con omisión de las proclamas y aun de insertarlo en el libro parroquial. Sus únicas solemnidades estaban constituidas por la presencia del párroco y de dos testigos de confianza, que se obligaban a mantener el sigilo pertinente. Se comentó que el Papa Benedicto XIV los admitió en su constitución Satis vobis de 17 de noviembre de 1741. Como podían originar muchos abusos y malos entendidos, debían de llenarse diversos requisitos: a) expresa autorización episcopal, pudiendo otorgarla el ordinario sólo con causa grave y urgentísima, como sería el caso de los que, habiendo vivido en concubinato, habían sido tenidos por legítimamente casados; b) diligente averiguación sobre las circunstancias personales de los contrayentes y, en particular, sobre su soltería o viudez; c) que el párroco respectivo u otro sacerdote de "experiencia, probidad y doctrina", amonestase a los contrayentes acerca de la necesidad de reconocer la prole y suministrarles ayuda y educación cristiana cumpliendo así con los deberes paternos y maternos, en particular, hacerlos bautizar comunicándolo al obispo, so pena que de no hacerlo así el matrimonio se haría público; d) no registrándose este matrimonio en el Libro parroquial, el certificado de haberse contraído debía ser enviado al obispo, quien lo archivaría en un Libro ad-hoc así como los certificados de los bautizos de los hijos y no haciendo esto en treinta días desde su ocurrencia, se haría público el matrimonio ${ }^{13}$.

Cierto es que en este trabajo sólo interesan los últimos, es decir los casamientos secretos, ocultos o de conciencia. El Pbro. Dr. Bunge ${ }^{14}$ en Buenos Aires, expresó sobre los documentos secretos que los comprendían y la función de la Iglesia Católica de salvaguardarlos ${ }^{15}$. En efecto, señaló que la existencia del Archivo Secreto quedó establecida en los cánones 489 y 490, lo que es obligatorio en la Curia diocesana correspondiendo a su obispo el guardado de su llave:

En diversos lugares del Código nos encontramos con referencias a documentos que deben guardarse en el archivo secreto de la Curia diocesana. Por ejemplo, con relación a la celebración del sacramento del matrimonio, las dispensas de impedimentos matrimoniales ocultos, concedidas en el foro interno sacramental, salvo que en algún caso la Penitenciaría apostólica decidiera en forma distinta, y el registro de los matrimonios celebrados en forma secreta ${ }^{16}$.

13 Ibídem, pp. 76-77; Donoso, 1861, vol. 2, pp. 414-415.

14 Bunge, 2007.

15 Ibídem, pp. 18-20.

16 Ibídem, p. 19. 


\section{LEGISLACIÓN CANÓNICA CON RESPECTO A LOS MATRIMONIOS SECRETOS. NOVEDADES EN LO HISTÓRICO, SOCIO-DEMOGRÁFICO Y CULTURAL}

Tal como fue expresado, una serie de características tuvieron lugar cuando se llevaron a cabo bodas secretas. De hecho, en el manejo de la sociedad y las familias hubo una verdadera competencia por el poder temporal entre la Monarquía y el Papado. Esto produjo que ambos manifestaran consideraciones que deslindaban atribuciones vinculadas al matrimonio. En efecto, durante el siglo XVIII en el orden civil, se debe advertir la legislación al respecto:

1. La Real Cédula y Pragmática Sanción de 23 de marzo de 1776 vinculada a matrimonios de hijos de familia, de Carlos III, aplicada en Indias por medio de la Real Cédula de 7 de abril de $1778{ }^{17}$. En Buenos Aires el Virrey D. Juan José de Vértiz la comunicó el 26 de septiembre de 1778; ella reglamentaba el matrimonio de acuerdo a la edad, la posición y la raza de los contrayentes ${ }^{18}$. Con el tiempo, se sumaron otras, así la Real Cédula expedida en Badajoz a 7 de febrero de 1796 vinculada a que en la Real Provisión de matrimonios de 23 de marzo de 1776 debían ser comprendidos indistintamente los militares ${ }^{19}$. Ello, aparte de las disposiciones anteriores para el fuero de estos últimos como por ejemplo, desde principios del siglo XVIII, la Real Cédula del 28 de diciembre de 1701, en donde se prohibía a los curas, a los párrocos y a cualquier otro religioso casase a los oficiales de la Monarquía de los ejércitos reales sin la correspondiente licencia.

2. La Real disposición del 28 de abril de 1803, por la que los hombres mayores de 25 años y las mujeres de más de 23 no debían solicitar autorización de los padres para contraer enlace. Sin embargo, subsistió la necesidad de la licencia del padre y, en defecto de éste, de la madre, los abuelos y aun del tutor, para los menores de 25 y las de 23.

3. Las Gracias al Sacar de 1791, y las prebendas en igual sentido anteriores (este tipo de gracias no eran nuevas en la etapa presente analizada de la administración de la Monarquía), con la posterior adecuación de dichas gracias en el año $1801^{20}$.

El Concilio de Trento del siglo XVI, Sesión XXIV, estableció que los vínculos matrimoniales para que fueran válidos, debían ser verificados ante la presencia del párroco, el libre consentimiento de los novios, en facie ecclessiae, por palabras de presente y no de futuro, con las tres proclamas corridas en consecuentes días festivos, y ante dos o más testigos. Aparte de ello, los matrimonios corrientes debían ser asentados en los libros de las parroquias respectivas.

17 Dougnac, 2003, p. 40; FAlCón, 2007, p. 17.

18 Dougnac, 2003, p. 40.

19 Ibídem, p. 40, cita 166; Dítz, 2008, p. 378. Por la R. O. de 11-IV-1750 se perdonó a un total de 223 oficiales del ejército, pertenecientes a todas las armas. Asimismo, dice: "Una década más tarde, en la circular de 20-V- 1760 se publicaba el indulto concedido a 18 oficiales, y en el registro documental de dicha circular también se reseñó la calidad de sus esposas: la mayoría hijas de militares o con grado distinguido y 7 de probable estado llano. Entre estas últimas, dos fueron consideradas indignas: la «viuda de un marinero y criada» y la hija de un músico". La autora cita la obra de BALDUQue, 2002, pp. 343-344.

20 TwinAm, 2009. 
A su vez, el decreto Tametsi (11 de noviembre de 1563), instituyó que se debía respetar la forma canónica ${ }^{21}$. A partir de entonces se prohibieron y declararon írritos los matrimonios clandestinos. Otro tanto ocurrió después con la disposición de Benedicto XIV de 17 de noviembre de 1741, que se refirió a la intervención de los padres en las bodas y esponsales de sus hijos y su Encíclica Satis Vobis ${ }^{22}$. Causa de esta normativa fue el abuso de los hijos de familia de contraer casamientos que los padres o parientes directos consideraban desiguales.

Chacón Jiménez y Méndez Vázquez señalaron que hasta la celebración de Trento se aceptaron los llamados matrimonios clandestinos, pero después de este Concilio dichos desposorios se prohibieron terminantemente ${ }^{23}$. Remontándose en el tiempo, los mismos autores transcriben las palabras de su significado:

Óigase lo que es un matrimonio clandestino, según la Iglesia, en lo que dice una ley de Partidas, tomándolo del Decreto de Graciano: Matrimonios encubiertos son quando los facen sin ningunos testigos, o quando los facen ante algunos, mas non demandan la novia a su padre, o a su madre, o a los otros parientes que la han en guarda ${ }^{24}$.

Hay que tener en cuenta que los esponsales clandestinos no fueron secretos en la acepción que se tiene de casamientos ocultos o de conciencia, ya que éstos siempre se realizaron con el consentimiento de la Iglesia Católica, los de los novios, la presencia del sacerdote y ante dos testigos que, por lo general, eran los propios progenitores de los contrayentes a los que también se les exigió guardasen secreto. Dicho de otra manera, la Iglesia promovió y concretó los matrimonios secretos en algunos y ciertos casos.

Sin embargo, el nombre de clandestinos y los secretos fueron manejados como sinónimos con la equivocación conceptual en que se incurrió. Al respecto Dougnac Rodríguez expresó con razón: "Además de la apuntada imprecisión en las fronteras entre esponsales de presente y matrimonio, la había entre esponsales, matrimonio secreto y matrimonio clandestino" 25 .

21 GHIRARDi - IRIGOYEN, 2009, p. 245

22 Colección en latín y castellano de las Bulas, 1790. GolmaYo, 1999, p. 1, dice: "Estos matrimonios, aunque son ocultos, no pueden llamarse clandestinos, porque la Iglesia los consiente y se celebran con arreglo a las leyes. Antes de Benedicto XIV eran realmente un asunto de conciencia y de buena fe si llegaba el caso de morir los testigos, siendo entonces muy incierta la suerte de los hijos, y no pudiendo tampoco reclamar nada la mujer por falta de pruebas. Benedicto XIV, por su bula Satis vobis, concilió todos los intereses con la mayor sabiduría, mandando que únicamente pudiera permitirlos el Obispo por causa grave, urgente y urgentísima, atendiendo a la cualidad de las personas (...). Dispuso también que se destinasen dos libros, uno para insertar las partidas de estos matrimonios, y otro para las partidas de los hijos que naciesen los cuales no podrían abrirse sino en el caso de tener que insertarse otras partidas, o por haber necesidad de administrar justicia, o si los pidiese alguno de los interesados por no haber otras pruebas. Es obligación del padre, y muerto éste de la madre, dar cuenta al Obispo, en el espacio de treinta días, de los hijos que hubiesen nacido; de lo contrario, cesa la obligación del secreto y se publica en seguida el matrimonio". Es de agregar que la carta encíclica Satis Vobis recogió también antecedentes en el Concilio de Letrán de 1215.

23 ChaCón - MÉndeZ, 2007, pp. 61-85.

24 Ibídem, p. 63. CHACón - BESTARD, 2011, pp. 325-385, contiene análisis que comentan la formación y constitución familiar según las normativas canónicas y las posteriores civiles.

25 Dougnac, 2003, p. 32. 
Ello produjo que autores que volcaran sus trabajos en ediciones historiográficas los anotaran como si los casamientos clandestinos o secretos surgieran de la misma situación, con las equivocaciones posteriores a que estos errores dieron lugar.

Ahora bien, ¿de qué forma inciden la gran cantidad de los matrimonios secretos en los cómputos histórico-demográficos-culturales normales de la sociedad y sus matrimonios? ¿Hubo numerosos subregistros en las actas parroquiales; se modificarían por ello las cifras que se manejan? ¿Fueron docenas, cientos, o muchos más? ¿Se trató de algo justamente, secreto, de lo que "no se hablaba", y por tanto no se conocía, porque los libros que los asentaban yacían en las cámaras privadas de los obispados o, en las salas parroquiales en donde la sociedad civil en tiempos anteriores no tenía acceso?

Nadie podía consultarlos, salvo personas con permiso y cuando ello fuera más que necesario en el primer caso, con autorización expresa del obispo que poseía la llave donde se recogían. Sin duda, reacción lógica de la Iglesia Católica en el amparo de sus feligreses quienes acudían a ella develando en confesión sus íntimas causas. Y caben otras reflexiones: ¿Los contenidos de las partidas de matrimonios que no siempre fueron iguales, se podían interpretar correctamente por los que las leían tomando conciencia que se trataba de matrimonios diferentes a los comunes? El tema, confundió a muchos historiadores prestigiosos: ¿Cómo escribir acerca de ellos, si no se ubicaban a primera vista las fuentes casuísticas directas que los atestiguasen? ${ }^{26}$. ¿Cómo llevar a una cuantificación estos matrimonios de manera global cuando era imposible analizarlos? ¿En algunas parroquias más que en otras, quedaron vestigios concretos e integrales de lo que se expresa?

En páginas anteriores se indicó sobre historiadores que se refirieron brevemente a lo expuesto: D. Rípodas Ardanaz; C. Jaúregui Rueda, J. Pico, en lo que hace a Buenos Aires y casamientos secretos. Los dos últimos en especial dentro del ámbito de la historia y genealogía de Argentina. La cuestión requiere del manejo de las pragmáticas reales en su siglo, como de las premisas establecidas por el Derecho Canónico.

Son de puntualizar otras preguntas: ¿Podía adecuarse un casamiento secreto -por ejemplo- con la Pragmática Real en cuanto a las Gracias al Sacar de 1791? De entrada, es de afirmar que no. Una cosa puntual fue la concesión de una gracia por medio del pago de dinero y, otra, un casamiento secreto aceptado por la Iglesia.

Por último, ¿cuál fue el estado civil (para la época) en que quedaron los hijos de los matrimonios secretos desde que no todos estos pasaron a ser anotados en los libros parroquiales de uso corriente? ${ }^{27}$. ¿Luego de pasados años, reclamaron

26 Fernández, 1997, utilizó los Libros secretos de Matrimonios de Murcia para observar varios casamientos de este tipo de comerciantes de España.

27 Donoso, 1861, p. 415, dice: "Que el párroco o sacerdote de experiencia que había llevado a cabo el matrimonio secreto tenía la obligación de aleccionar a los padres sobre la reconocimiento de la prole y la necesidad de brindarle asistencia, educación, alimentos, e instituirla heredera, "previniéndoles que, luego de que les nazca un hijo, deben dar cuenta al Obispo, del bautismo que se le confirió, con expresión del lugar y tiempo, y de los nombres tanto suyos como de dichos hijos y padrinos; y que si no lo ejecutan así, se publicará el matrimonio...". Quinteros, 2010, pp. 267-268; KonETZKe, 1962, pp. 401-402, cuando se expresó que los hijos padecían muchas dificultades por no estar sus partidas de bautismos correctamente presentadas, "ni hallarse en los libros parroquiales el matrimonio de sus padres...". 
su inserción para poder a su vez contraer nupcias como descendientes legítimos? Este renglón tiene abierta la posibilidad hermenéutica de múltiples aproximaciones directamente ligada a los aspectos históricos-demográficos-culturales ocurridos en las Gobernaciones y, después, en el Virreinato del Río de la Plata que es el tema puntual que se abarca.

En la actualidad, con las posibilidades de consultas en los registros parroquiales digitalizados, se presenta un marco teórico insospechado.

En efecto, cuando no se ubica la partida matrimonial de determinadas parejas por ser secreta y no figurar su inclusión en los libros comunes, la búsqueda de descendientes que más tarde casaron, en los libros parroquiales en las bases de datos de los mormones, faculta interpretar si los hijos fueron anotados asimismo como naturales o legítimos.

\section{ANTECEDENTES SOBRE LA CONCRECIÓN DE CASAMIENTOS SE- CRETOS EN HISPANOAMÉRICA}

Consta que en Hispanoamérica ${ }^{28}$, alusiones sobre los matrimonios secretos se ubican en la documentación del cardenal Lorenzana en momentos del IV Concilio Provincial Mexicano. Fue estudiado por Luisa Zahino Peñafort como recopiladora, y posee una Introducción de L. Arroyo Zapatero y de M. Blázquez, los que afirman que en el reinado de Carlos III se acentuaron más que nunca los privilegios regalistas de la Iglesia en Indias ${ }^{29}$. Agregan que sostuvo el Regio Patronato, "como un derecho inherente a la Corona, sin conexión ninguna con el pontificado. En la práctica, esto suponía la subordinación de la jerarquía eclesiástica en Indias al poder real para llevar a cabo la política reformista del monarca" ${ }^{30}$.

Al tratar el tema de esponsales y matrimonios el obispo de Puebla solicitó se mandase que los matrimonios secretos se publicaran para obviar los escándalos. A ello respondió "el prelado de los Camilos", que ello provocaba una real dificultad ya que si se daban a conocer los "de aquellos que los contraen así por ser creídos casados no siéndolo, a que se le respondió no hablarse de esto" ${ }^{31}$.

28 ZAhino, 1999, pp. 209 y ss. explica cómo desde la muerte de Carlos II y el advenimiento de Felipe V se extremaron las atribuciones del monarca con respecto al poder del papa.

29 Ibídem, pp. 209 y ss.

30 Ibídem.

31 Ibídem, p. 656. 
Aspectos a tener en cuenta son que hubo matrimonios secretos no solo concertados después del Tridentino ya que de hecho existieron desde antiguo entre los nobles ${ }^{32}$ y en el marco morganático ${ }^{33}$.

Es decir que disímiles causas podían llevar a la concertación de un matrimonio secreto con el consentimiento expreso de la Iglesia Católica. Sin duda en el concepto cristiano ello lo hizo para la salvación del pecado de las almas de sus feligreses.

Hubo varios casamientos secretos en Hispanoamérica durante la etapa de Antiguo Régimen. Así en Filipinas, en donde existen documentos de don Gaspar de la Torre, su gobernador, dando cuenta que don Cristóbal Pérez Arroyo, fiscal de la Audiencia ${ }^{34}$ había solicitado licencia para casarse cuando ya lo estaba desde tiempo antes (desde 1738), según data fechada en Manila del 31 de julio de 1742. Al año siguiente murió, cuando se encontraba en diligencias para que su matrimonio fuera considerado válido. Se ordenaron averiguaciones para conocer si la ahora viuda María Josefa de Morales tenía parientes en Manila. Igualmente, si Cristóbal Pérez Arroyo había recibido el sacramento del matrimonio con dicha María Josefa sin tener la correspondiente licencia del Rey ${ }^{35}$. Estas diligencias se debían a que de la Torre estaba al tanto de la Real cédula del 24 de mayo de 1740 que prohibía el casamiento de los oidores, sus hijos y otros ministros y fiscales de las Audiencias ${ }^{36}$, por lo que era su función primordial velar para que se cumpliese.

32 Golmayo, 1999, p. 1, dice: “Durante el régimen feudal había un matrimonio que se llamaba morganático, el cual se celebraba según las leyes eclesiásticas, pero bajo una condición impuesta por las leyes feudales (...) según aparece del libro II de los Feudos, tít. XXIX: Que si alguno, teniendo hijo de un primer matrimonio celebrado con mujer noble, no pudiendo guardar continencia después de la muerte de ésta, se uniese en concubinato con otra menos noble y quisiese contraer matrimonio para no continuar en el pecado, se desposen con la condición de que ni ella ni sus hijos tengan derecho a suceder en los bienes paternos, excepto en aquella parte o donación que les señale al tiempo de los desposorios. Que si no existen hijos del primer matrimonio, puedan los del segundo suceder en los bienes paternos, pero no en los feudos. Se llama este matrimonio morganático, de la palabra morgengap, que significa donación. Ésta al principio era arbitraria; después mandó Luitprando, rey de los lombardos, que no pudiese exceder de la cuarta parte de los bienes, para que no saliesen tan perjudicados los hijos del primer matrimonio". Es válida la aclaración que este tipo de matrimonios siempre existieron. La propia realeza y los nobles los solicitaron en sus pedidos de dispensas para matrimonios por la necesidad de concertarlos fuera del ámbito de las dispensas comunes. En oportunidades, "las multas" o, remedios aconsejados como penas en esta esfera matrimonial fueron altas.

33 Un matrimonio secreto morganático fue el de la reina María Cristina de Borbón de España, viuda del rey Fernando VII, con el sargento Fernando Muñoz. Al respecto se ha dicho: "El 29 de septiembre de 1833 murió Fernando VII y el 4 de octubre estalló la primera guerra carlista. Sólo Inglaterra y Francia reconocieron a la reina, que inauguró su gobierno dictando medidas de carácter ampliamente liberal. (...) La reina se había casado con el sargento Fernando Muñoz, y no le quedaba más apoyo que el del ejército, acaudillado por Espartero. Estando la reina en Barcelona, el 14 de julio de 1840, dimitió Espartero, y tres días después estallaron motines por toda España. La reina ordenó a Espartero que acudiera a reprimir el pronunciamiento del 4 de septiembre y, ante la negativa del general, embarcó para Marsella el 17 de septiembre. (...). En el destierro la acompañaba su esposo morganático. Cuando una sublevación dirigida por Narváez arrojó del poder a Espartero y fue declarada Isabel II mayor de edad, María Cristina pudo volver a España. En 1845 se hizo público su matrimonio con Fernando Muñoz, con quien tuvo ocho hijos, que recibió el título de duque de Riansares. [La Reina María Cristina] Murió en Saint Adresse (Francia) el 23 de agosto de 1878". En http://censoarchivos. mcu.es/CensoGuia/fondoDetail.htm?id=442870; FALCón, 2007, p. 29.

34 Expediente sobre matrimonio de Cristóbal Pérez Arroyo (1743-1744). AGI, Audiencia de Filipinas. Se trata de los legajos: 246, 247, 248, y 249 (1741-1743).

35 Ibídem. Expediente sobre matrimonio de Cristóbal Pérez Arroyo, Manila, 26 de junio de 1743.

36 Ibídem. Expediente sobre matrimonio de Cristóbal Pérez Arroyo, Manila, 17 de junio de 1743. 
Sin embargo, las autoridades civiles manifestaron no conocer nada en tal sentido -al menos esto es lo que afirmaron- de lo ocurrido en sus jurisdicciones de gobierno ${ }^{37}$. Por de pronto, el gobernador D. Manuel de Castro manifestó a S. M. el 30 de agosto de 1797 que se habían concretado casamientos:

hechos en las plazas de su mando con oficiales militares y otros sin real licencia, de la dificultad de probarlos, de la responsabilidad en la tolerancia, que según ordenanzas de 30 de octubre de 1760, podía acaso imputárseles, y de su solicitud para el descubrimiento de tantos perjuicios como son consiguientes ${ }^{38}$.

Para dicho gobernador la situación era delicada al expresar que a pesar de sus esfuerzos no había podido encontrar documentación de ellos. El mismo Castro agregó:

Siempre supuse muy difícil o imposible encontrar esta [situación palpable], porque no es regular que declaren el cura o sacerdote comisionado, y menos los contrayentes por las penas a que están sujetos, ni los testigos que se considera serán los parientes más inmediatos y de mayor reserva de quienes tengan confianza que los expongan a ellas con la falta del silencio ${ }^{39}$.

A ello agregó que en Puerto Rico, el obispo D. Manuel Jiménez Pérez contestó al Gobernador de S.M.C. que no tenía idea de los matrimonios secretos que se hubieran generado en su ámbito eclesiástico ${ }^{40}$. No obstante, corría el rumor que su propio hermano había sido casado en secreto por el propio obispo, con $\mathrm{D}^{\mathrm{a}}$ María del Carmen Casado. Venía a ventilarse el asunto de incógnito en mérito al pleito por palabra de matrimonio que mantenía Da Petrona González con el subteniente retirado D. Manuel de Andino en el Consejo de Guerra.

Al gobernador de Puerto Rico, D. Manuel de Castro, le constaba que en distintas parroquias y también por disposición del mismo Ilustrísimo obispo se habían concertado nupcias secretas. En esta afirmación señaló que entre los años 1776-1777 varios prelados llevaron a cabo matrimonios de la índole expresada. Así, el establecido privadamente entre el Auditor de Guerra D. Francisco Rafael Monserrate quien mantenía un proceso del que salió finalmente airoso por indulto del rey fechado el 19 de enero de $1778^{41}$. En cercanos momentos se supo de otras nupcias de igual tenor, entre el fiscal de la Real Hacienda de Puerto Rico con una dama del lugar, según lo informado el 15 de octubre de 1796.

\footnotetext{
37 Tribunales Eclesiásticos. Matrimonios secretos, Puerto Rico, 1798. Archivo General de Simancas (en adelante AGS), leg. 7231, 50, folios 1-32.

38 Ibídem. El gobernador de Puerto Rico a su S.M.C., Reservada n 3, Puerto Rico, 30 de agosto de 1797. AGS, leg. 7231, imagen 1.

39 Ibídem. El gobernador de Puerto Rico a S.M.C. Reservada nº 3, Puerto Rico, 30 de agosto de 1797. AGS, leg. 7231, imagen 1.

40 Ibídem. El gobernador de Puerto Rico a S.M.C. Reservada n 3. Puerto Rico, 30 de agosto de 1797. AGS, imagen 2/32.

41 Ibídem. El gobernador de Puerto Rico a S.M.C. Reservada no 3. Puerto Rico, 30 de agosto de 1797. AGS, imagen 4/32.
} 
En resumen, en la mayor parte de los ámbitos de la Monarquía se consumaron matrimonios secretos en contra de sus disposiciones. Si esto ocurría con los funcionarios reales, puede afirmarse que otro tanto acaeció en contra de lo dispuesto por la Real Pragmática de 1776, que rigió en Hispanoamérica a partir de 1778; sumado a los requisitos establecidos para los militares -que, por marcar una fecha- se exigieron en las Reales Circulares del 12 de enero de 1784, 10 de febrero de 1785, y lo que se repitió el 18 de septiembre de 1788. En estas circunstancias, los militares debieron pedir licencia, lo mismo que los oficiales del cuerpo de la marina quienes se encontraban en idéntica legislación. Puede afirmarse que el no cumplimiento a las ordenanzas llevó a que se aplicaran serias sanciones (degradación del grado militar, no obtención de los salarios, entre otros), a los que contraían nupcias sin la licencia militar o naval ${ }^{42}$, incurriendo en un casamiento secreto.

Deben asimismo considerarse las nupcias secretas, ocultas o de conciencia que tuvieron algunas viudas que no querían perder la pensión militar si volvían a contraer nupcias. En este orden existía la Real Cédula del 23 de diciembre de 1766 que indicó que no les correspondía el Montepío militar de sus esposos fallecidos ${ }^{43}$.

La documentación permite conocer que hubo este tipo de casamientos en Perú, en Chile, Cuba y en Nueva España. Precisamente, en Perú puede mencionarse como ejemplo de casamiento secreto el del Capitán catalán de Granaderos del Callao, don Juan de la Roca. Este contrajo enlace en Lima con doña Cecilia de Milla y Villar el 25 de marzo de 1776; se efectuó con la dispensa de las tres proclamas y con carácter reservado ${ }^{44}$.

En el mismo territorio peruano, en Trujillo, se encuentra otro casamiento llamado "clandestino" que, en realidad, mantuvo la forma secreta, tal es el efectuado por doña María Isabel Cavero con un clérigo tonsurado, don Vicente García de Achurra, el que se efectuó el 16 de junio de 1794 a pesar de la terminante oposición del padre de la novia ${ }^{45}$.

Puede agregarse a don Manuel José Pardo Ribadeneyra y González Bañón, Regente de la Real Audiencia del Cusco, quien se casó secretamente con doña Mariana de Aliaga y Borda, hija del marqués de Fuente Hermosa y hermana de la marquesa de

42 Pueden mencionarse las disposiciones de matrimonios para el cuerpo de oficiales navales, así los dirigidos a los alféreces de fragata del 27 de agosto de 1785 cfr.: Prontuario alfabético, MDCCXCIV, p. 323. Por su lado Dougnac, 2003, p. 106, señala que por Real Orden Circular del 21 de agosto de 1790 se resolvió que las viudas y huérfanos de quienes hubiesen casado sin las licencias pertinentes no podían acceder a los derechos de Montepíos. 44 AGI, Audiencia de Lima, 656, n. 29, 7.

43 Ferrer, 1997, p. 162.

44 Carta de Manuel de Guiror, virrey del Perú, a José de Gálvez, secretario de Indias, Lima, 1797, nº 195 (Copia de las diligencias hechas para acreditar el derecho a los beneficios del Montepío Militar de María Cecilia de Milla, viuda del capitán de Granaderos del Batallón del Callao, Juan de la Roca). AGI, Audiencia de Lima, 1798-1790, 656, $\mathrm{n}^{\circ} 29$, folios 323-330.

45 FALCón, 2007, trabajó con importantes citas bibliográficas que trae el caso de un matrimonio secreto de una dama de la sociedad de Trujillo con un hombre de la Iglesia que había recibido las órdenes menores (p. 24). En el caso que el autor relata no se trató de un matrimonio clandestino, tal como lo menciona en algunas ocasiones (pp. 1, 31, 45, 46, 49, 51, 52). El matrimonio después de Trento fue la concesión de un sacramento aceptado por la Iglesia Católica a los contrayentes por lo que de ninguna manera podía ser un hecho clandestino. Diferimos en lo expresado por el autor en p. 51, ya que -además- instituido el casamiento secreto no debían luego ratificarlo, solo podía pasar a ser anotado en los libros comunes de matrimonios del Obispado. 
Castell Bravo del Rivero ${ }^{46}$. En 1806 con el nacimiento de su primogénito Felipe en Perú, aquél obtuvo la licencia real para consolidar sus nupcias.

Para Chile se cuenta con ejemplos, así los del capitán de Dragones don Juan Miguel de Benavente y Roca que casó secretamente con doña María Juana Álvarez y Manzanos. Don Tomás de Roa Alarcón y Correa, tío del novio, a la sazón Obispo de la Santa Iglesia de la Concepción, intervino solicitando el indulto del rey luego de las nupcias. Se adujo que la esposa con la que había casado "unos 6 años antes", era de "distinguida familia". Cabe la pregunta: ¿fue dicho obispo quien realizó el matrimonio secreto de su sobrino? ${ }^{47}$.

En Cuba hubo nupcias sin licencia como las tratadas; así, la de don Francisco Mendieta, Subteniente del rey de España en el Regimiento de Puebla ${ }^{48}$.

Por su lado, en Nueva España, las fuentes documentales indican que el teniente veterano de milicias, a la sazón agregado en este territorio mexicano, don José Vigil de Quiñones consumó un casamiento secreto. En este caso el rey, en mérito a su actuación, le concedió el indulto por lo que su partida matrimonial pasó a los libros de matrimonios corrientes ${ }^{49}$.

Más desposorios de conciencia se exponen en las páginas siguientes. Mientras tanto, el relato llevó a observar cuestiones de peso ocurridas en tiempos contemporáneos a la centuria del dieciocho.

\section{ACCIÓN DEL VIRREY LORETO ${ }^{50}$ EN ORDEN A LAS NUPCIAS REALI- ZADAS EN EL VIRREINATO DEL RÍO DE LA PLATA}

Si se lleva el marco a la casuística rioplatense, una cuestión ocurrida en Buenos Aires a fines del siglo XVIII desató, justamente, controvertidas desavenencias entre los que pujaban por mantener el poder temporal. En un párrafo "Real Patronato: ocurrencias con el reverendo obispo de Buenos Aires en punto de esta soberana regalía, y otros de la jurisdicción diocesana, y de la eclesiástica castrense, y antecedentes en sede vacante" ${ }^{51}$.

Disposiciones encomendadas en fecha anterior por el rey Carlos III (gobernó España entre 1759-1788, fallecido en este último año), dan idea de la importancia de mantener el Patronazgo Real, sostenido por el virrey del Río de la Plata, haciendo guardar a los prelados eclesiásticos como a los de las órdenes religiosas se respetara lo concedido a los Reyes de España por la Santa Sede Apostólica con el agregado de las subsiguientes provisiones. Con estas medidas se procuró que los prelados no embarazaran la conducta política de la Monarquía, como algunos lo habían intentado.

\footnotetext{
46 SiEgrist, 2014, p. 27.

47 Indulto concedido a D. Juan Miguel de Benavente y Roca por haberse casado sin licencia, Madrid, 7 de abril de 1799. AGI, Secretaría de Estado y del Despacho de Guerra, leg. 7232, n 28, folios 128-136.

48 Ibídem, leg. 7232, 29.

49 Indulto concedido al teniente José Vigil de Quiñones de la falta en que incurrió por haberse casado sin licencia. 1794. AGI, Secretaría de Estado y del Despacho de Guerra, leg. 7227, nº 75, folios 366-373.

50 Don Nicolás Felipe Cristóbal del Campo y Rodríguez de Salamanca nació en Sevilla en 1723 y falleció en Madrid en 1803. Fue el tercer virrey del Río de la Plata gobernando el territorio entre 1784 hasta 1789.

51 Revista del Archivo General de Buenos Aires, 1872, vol. 4, p. 520.
} 
El virrey comentó que a su arribo en 1784, se hallaba vacante la elección de un Provisor, lo que recordó al reverendo metropolitano (como el de la Comisaria de Cruzada), la que por indicación del funcionario virreinal recayó en el Dr. D. Miguel José de Riglos, arcediano titular, quien ejercía la jurisdicción eclesiástica ${ }^{52}$. En torno de estos sucesos, pronto las diferencias entre el virrey y el arcediano se hicieron notar.

En efecto, haciendo causa común con el deán Riglos, el Dr. D. Juan Baltazar Maciel, canónigo magistral del Obispado rioplatense no dudó en hacerse nombrar en el deanato vacante, en momentos en que el primero -entrado en años- no podía ejercer totalmente sus funciones. Las distintas actitudes con respecto al manejo de la sociedad, fuera en el ámbito civil del monarca o, en el eclesiástico a través del obispo o su reemplazo en sede vacante, provocaron rápida indisposición entre las partes al faltar el respeto -según el virrey- a las regalías y al decoro de la "Potestad Real" 53.

Pronto las facciones se dividieron: el propio Cabildo eclesiástico desoyó las máximas impuestas por el maestre escuela D. Juan Baltasar Maciel, presentándose parte de ellos al magistrado del gobierno confesando no querer participar de los acontecimientos que ocurrían. En tales términos, pidieron la separación de D. Miguel José de Riglos, como provisor, y se añadió que una "capilla" [Parroquia del Socorro de Buenos Aires], volviera a sus funciones luego de estar suspendida ${ }^{54}$.

El virrey en relación a dichos casamientos expresó que, dedicado el arcediano Riglos a dar licencias para matrimonios secretos en el tiempo que despachó la jurisdicción diocesana, ocurrieron causas graves:

fue notable, el escándalo que resultó de esta facilidad y de los medios que se habían empleado para tales despachos, atropellando, no solo los fueros y exenciones, sino las Reales Pragmáticas y lo más sagrado de las disposiciones de la Iglesia para la administración de este sacramento y su constancia: por esto en 5 de julio de[17]87, con reserva pasé un billete al Cabildo sede Vacante, de que será muy conveniente mande V.E. al secretario de Cámara le dé inteligencia, y de las resultas; como asimismo de lo que con el número 729, por mano del Excmo. Señor Marqués de Sonora, representé a S.M. en esta razón, sobre que con fecha 11 de noviembre de [17]87 me avisó de Real Orden el Exmo. Sr. D. Antonio Polier, haber resuelto el Rey que mi informe se agregase al expediente general de la prisión de Maciel y separación de Riglos, teniendo yo por conforme en estas circunstancias advertir aquí que, con los números 643 y 679, di cuenta a S.M. por medio de dicho señor Marqués de Sonora, con documentos de lo actuado respecto al doctor Maciel, que este eclesiástico en sus recursos hizo pasar en la corte prisión, al mismo tiempo que acá manifestaba complacerse de haber mejorado de temperamento, y que la disposición tomada en fuerza de lo que allí resulta inclusa la consideración de que por el influjo él era el provisor, estando por Real Cédula impedido de poderlo ser, se redujo a que esperase en Montevideo a su Prelado... ${ }^{55}$.

En efecto, el Dr. Baltasar Maciel debió dirigirse a Montevideo expulsado de Buenos Aires por orden del Virrey Marqués de Loreto como luego se alcanza a observar.

$\begin{array}{ll}52 & \text { Ibídem, p. } 522 . \\ 53 & \text { Ibídem, p. } 523 . \\ 54 & \text { Ibídem, p. } 524 . \\ 55 & \text { Ibídem, p. } 524 .\end{array}$ 
Está clara la disputa por el poder que la Iglesia mantuvo con la Monarquía en cuanto a dirimir en el matrimonio de sus feligreses, su descendencia legítima o legitimada, la sucesión de los bienes derivada de esta condición en mérito a la salvación de las almas, el respeto a los sacramentos y la dispensa ante los pecados cometidos para alcanzar la vida eterna. De hecho, sin este último punto espiritual de conocimiento en el contexto de la fe cristiana algunas interpretaciones suelen sólo sintetizarlas como la ambición de la Iglesia por mantener su poder temporal.

Si se continúa con el relato, en Buenos Aires se suponía próximo el arribo del nuevo Obispo. Mientras tanto había sido expulsado de la ciudad porteña el Canónico Maciel, quien gravemente enfermo atrasó su viaje:

que ya no creía convalecer; después su navegación por el error de un piloto, sucesivamente por la arribada que hizo a la Bahía de todos Santos (sic), y que antes de su desembarco en el puerto de Montevideo falleciese allí... ${ }^{56}$.

En dichas circunstancias, el nuevo obispo en el Río de la Plata don Manuel Azamor y Ramírez (1788-1796) ${ }^{57}$ arribó a Montevideo dando desde aquí poder el 16 de abril de 1788 al deán Pedro Ignacio Picazarri para que tomara a su cargo la diócesis en Buenos Aires, en lugar del anterior arcediano don José Miguel de Riglos.

Así las cosas en la capital rioplatense, el virrey tuvo noticias de que el prelado había arribado a Montevideo pero no le había avisado a pesar de residir en esta ciudad muchos días, aparte que aquél primero había dado comienzo a su actividad pastoral con una serie de confirmaciones de los feligreses en esa ciudad y en otras cercanas. Cabe destacar, que tampoco el Obispo dio luego avisó de su arribo a Buenos Aires, ni al ayuntamiento. Como si fuera poco, se hospedó en el convento franciscano donde lo estaban esperando con conocimiento exacto de su llegada.

Se aclaran estos contratiempos y diferencias porque hubo diferentes hechos que pronto se desarrollaron. Así, ya ubicado el obispo Azamor y Ramírez en Buenos Aires fue a ver al virrey el que según dijo, lo esperaba, "sin ningún resentimiento". No obstante, pronto el Prelado dio muestras de que no estaba de acuerdo con dar explicaciones al funcionario máximo real: “... de modo que da a entender con esta conducta -diría el marqués de Loreto-, que es el árbitro, y que ni tendrá aprobado aquel paso único que dieron con el Superior Gobierno sus familiares [que personalmente le habían ido a ver]"58.

Las quejas continuaron con respecto al comandante del Resguardo de Montevideo D. Francisco de Ortega, con quien el obispo había estrechado amistad. Las desavenencias llegaron hasta la mujer del mismo Ortega y a su servidumbre ya que los últimos no acudían al precepto de la misa con acuerdo de la cónyuge de ese funcionario. En fin, múltiples problemas que el virrey expresó no poder dejar pasar $^{59}$, sin menoscabo de su investidura.

56 Ibídem, p. 524.

57 En las páginas del Arzobispado argentino están indicados los años de su gobierno eclesiástico (1786 -1796). Arzobispado de Buenos Aires. http://www.arzbaires.org.ar/inicio/menu_historia.html.

58 Revista del Archivo General de Buenos Aires, 1872, p. 526.

59 Ibídem, pp. 526 y ss. 
Sin embargo, los asuntos más serios derivaron de las licencias otorgadas para concertar enlaces secretos por quien había sido el provisor de la Iglesia Metropolitana D. Miguel José de Riglos, a espaldas de la información del virrey que solicitaba saber lo ocurrido. Entre ellos, los oficiales para poder casar con las mujeres de su elección y los permisos que, hora el rey, el virrey, o su superior, podían conceder ${ }^{60}$. ¿Cómo manejarse con situaciones extremas en donde las personas querían contraer nupcias y pasaban meses o años sin lograrlo? ¿Cuántos concubinatos se dieron en estas ocurrencias, en momentos en que las relaciones fuera del marco del sacramento eran considerados pecados graves y sancionados con rigor?

En la documentación consultada, hay renglones que clarifican aspectos poco divulgados. Son de resaltar las partidas de matrimonios de una iglesia de la ciudad de Buenos Aires correspondientes al siglo XVIII. En ellas existe una sección que corre entre febrero de 1786 hasta el comienzo del año siguiente, en donde los asientos se encuentran desaparecidos. En relación con estas partidas matrimoniales de la Iglesia del Socorro, E. Rodríguez de Soaje Pinto, transcribió lo que los originales dicen textualmente:

Nota: Desde esta fecha [14 de febrero de 1786] hasta el 15 de enero de 1787, se suspendió la ejecución. Los matrimonios que ocurrieron fueron disposición voluntaria del Diputado de la Jurisdicción Eclesiástica e Incompetente Juez en ésta parte, cuyo conocimiento era reservado a la Sede Vacante, como consta de autos (sic) ${ }^{61}$.

Cierto fue que en el lapso en que gobernó el Dr. D. Miguel José de Riglos se produjeron varias anomalías y esto en relación con lo ocurrido en la mayoría de las Iglesias de Buenos Aires. En un Sumario que ordenó llevar a cabo el marqués de Loreto para conocer sobre las bodas secretas formalizadas en esta ciudad, descubrió la realizada entre el oidor de la Audiencia, don Tomás Ignacio de Palomeque con doña Andrea de Albizuri el 14 de septiembre de 1785. Estas nupcias tuvieron posterior certificación del 19 de septiembre de 1787, extendida por el Dr. Vicente Arroyo:

quien, en su momento, como cura rector semanero de la Catedral y en vista del documento por el que le constaba la legítima celebración de dicho matrimonio, había asentado la correspondiente partida en la forma debida y ordinaria, i.e., presumiblemente, en el libro común de matrimonios ${ }^{62}$.

60 Beverina, 1992, p. 282 y ss. expresa que en Buenos Aires existieron dos regimientos: el de Dragones y el Fijo de Caballería. Estaba comandado por un Coronel, secundado por un Teniente coronel, a la sazón jefe del segundo escuadrón y de una de sus compañías. Por el año 1744 existió en Buenos Aires un cuerpo de dragones compuesto por 8 compañías con setenta y siete plazas cada una. En 1774 en la ciudad de Buenos Aires había 8 compañías de dragones, lo que totalizaba 516 plazas. En 1803 su comandante fue el brigadier José Ignacio de la Quintana, secundado por el Coronel Manuel Gutiérrez y el Sargento mayor coronel José María Calazeyte"; FrADKIn, 2014, pp. 124-150, sostiene que en los años: “...1714 y 1810 el Ejército de Dotación en América contaba con un $15 \%$ de efectivos de caballería". Entre las milicias la situación era muy desigual: "De acuerdo al listado de cuerpos milicianos proporcionado por Marchena, puede calcularse que, entre 1760 y 1810, las unidades de caballería y dragones eran el 39,7 \% de las milicianas, pero en algunas zonas como Nueva España, Perú, Chile, Chiloé y el Río de la Plata rondaban o superaban el 50 \%, mientras que en otras zonas el porcentaje era muy inferior", pp. 119-125.

61 R[ODRÍGuEZ] O.R. DE SOAJE, 1999, p. 38.

62 RíPODAS, 1977, p. 82, cita 46 y pp. 82-83. 
Es de subrayar que en la Memoria del virrey Loreto a su sucesor en el Virreinato del Río de la Plata el marqués de Arredondo, se cita al arcediano José Miguel de Riglos quien fuera convocado para que diera respuestas concretas de este tipo de nupcias, pero éste se negó rotundamente, como a admitir la existencia del enlace de Palomeque ${ }^{63}$.

En torno de estos sucesos una parte de la sociedad participó de situaciones anómalas ante el sacramento del matrimonio cuya normativa (vigente en el siglo XVIII) yacía en el Concilio de Trento y el manejo puntual del Derecho Canónico que hizo la Iglesia -sumado a la Encíclica Satis Vobis de noviembre de 1741-, al otorgar ciertas gracias de esponsales a sus feligreses cuando el poder temporal de la Monarquía no lo concedía y/o los ceñía a encuadres legales no deseados. Un renglón histórico concreto es el vinculado a las fuerzas terrestres del ejército.

M. Gil Muñoz dice que en España asimismo se había generado el problema con los militares. Expresa que después de los indultos de abril de 1750, de mayo de 1760 y demás órdenes reguladoras, existió la constancia de una costumbre continua de matrimonios secretos.

La Iglesia fue partícipe directa de los casamientos de muchos militares (fundamentalmente oficiales desde el rango de capitán para arriba) ya que su orientación buscó amparar las almas en pecado, desde que los mismos, -por indicar parte de los contrayentes- no lograban las licencias para casarse ${ }^{64}$ y tenían en el tiempo concubinatos o sostenidas relaciones sexuales.

Colón de Larreátegui señala que los desposorios sin licencia podían tener consecuencias muy graves, como la pérdida del puesto logrado después de años y la negación de la pensión a las viudas ${ }^{65}$, a lo que dedicó largos párrafos ${ }^{66}$. Con referencia a los sargentos y cabos hubo directivas para que estos solicitaran licencia para casarse y en caso de desobediencia se les avisó que serían retirados de sus cargos pasando a la categoría de soldados ${ }^{67}$. De manera que el indulto del rey podía dejar sin efecto el fin de una carrera militar, ante el desacato cometido de casarse sin la licencia pertinente.

Se debe pensar en la obediencia que los cuerpos del ejército debían a sus superiores en cumplimiento de sus propias funciones. Ello se complicaba por la legislación civil vigente que comprendía a los hijos de familias, así la Pragmática Sanción de Carlos III de 1776 aplicada en Hispanoamérica en 1778 citada anteriormente, de que no incurrieran los cuerpos militares en la elección de su cónyuge si tenía notoria desigualdad social. Estas circunstancias se agravaban en la medida que el cargo militar era superior. Como si fuera poco se debe recordar lo que el rey Carlos III estableció por Circulares del 12 de enero de 1784, 10 de febrero de 1785, y lo que se repitió el 18 de septiembre de 1788, ya citadas, con respecto a la necesaria licencia que debían tener los militares para poder casarse.

63 Ibídem, p. 84, cita 55. El marqués de Loreto gobernó como virrey del Río de la Plata entre 1784-1789; Siegrist, 2014, p. 29. Testamento de Manuel Gallego, Buenos Aires, 1808. Archivo General de la Nación. Argentina, Sucesión $\mathrm{n}^{\circ} 5903$.

64 GIL, 2004, p. 107.

65 VÁzQUEZ, 2007, pp. 103-109.

66 Colón, 1828, II, p. 441.

67 Ibídem, II, p. 441. 
Por otro lado, conocido es que las novias de militares que deseaban contraer nupcias con oficiales reales debían llevar al matrimonio una dote de 3.000 pesos fuertes, lo que podía ser obviado si se trataba de hijas de otros oficiales. Del mismo modo, llegó a existir exención de dote para las hijas de consejeros togados o fiscales de guerra que casaran con militares, buscando mantener la posición de nivel social de este encuadre social ${ }^{68}$. Se dijo, además, que la Monarquía trató de formar una verdadera "aristocracia" del cuerpo de oficiales, de allí que exigía la paridad social de los casamientos con mujeres de la sociedad local o de la misma España ${ }^{69}$.

En este espacio no es posible extenderse en estos acápites de por sí realmente sustanciosos, ya que se trata de aspectos históricos que necesariamente merecen ser tratados con un criterio de análisis distinto acordes a los espacios y tiempos que se estudien.

Si lo anterior es válido para lo ocurrido con los oficiales debe entenderse que los casamientos secretos y su temática impactaron en todos los temas de parejas con problemas para casarse de manera normal.

Para el lapso que corre entre febrero de 1784 hasta diciembre de 1786 se cuenta con un Manuscrito ${ }^{70}$ que se consideraba perdido. En él se expresa toda la problemática ocurrida entre el Dr. Miguel José de Riglos y el marqués de Loreto, Virrey del Río de la Plata. El primero negó continuamente la existencia de casamientos secretos en general, hasta que el funcionario del rey mandó realizar un Sumario con actuación del Cabildo Eclesiástico de Buenos Aires.

Se hace mención a lo ocurrido en la Catedral de Buenos Aires (Iglesia de La Merced) entre principios de 1784 hasta agosto de 1786. Esto fue coincidente con el Manuscrito ${ }^{71}$ que contiene el Sumario que el marqués de Loreto levantó contra el Canónigo Dr. Miguel José de Riglos por las anomalías que efectuó al casar a varias personas, secretamente, sin su conocimiento.

En la Catedral de Buenos Aires, sobre un total de 135 nupcias se concedieron 19 con dispensa de proclamas (14\% aproximadamente).

68 GIL, 2004, pp. 109-110. La autora aclara que en 1796 se modificó el reglamento del Montepío militar: "Se mantuvo el principio de privar de empleo al oficial que se casara sin Real Licencia; se especificaba la calidad noble de las futuras esposas y la dote que debían aportar, que seguía siendo de veinte mil reales para las nobles y cincuenta mil para las del estado llano. El grado para casarse seguirá siendo el de capitán, pero el cambio que experimenta este reglamento es que el oficial debía aportar sesenta mil reales para su manutención con el fin de asegurar una vida decorosa" (...). Asimismo: "De las disposiciones publicadas sobre la regulación de los matrimonios se deduce cómo estas medidas limitaban la dinámica normal de los casamientos con respecto al resto de la sociedad, ya que motivos de carácter social al exigir nobleza, económicos con la exigencia de una determinada dote, y estratégicos al señalar que ... la carga del matrimonio les acobardaba..., son razones con que se trataba de justificar estas leyes. Del incumplimiento de estos requisitos se ocupaba el Derecho Penal Militar con sanciones como la separación del servicio a los oficiales, y a los sacerdotes" ...caer en real indignación..." "y expropiación de temporalidades".

69 DíEz, 2008, p. 378.

70 SiEGRIST, 2016.

71 Ibídem. 


\section{Cuadro no 1}

\begin{tabular}{|c|c|c|}
\hline Crespillo & Ignacio & Bs. As. $17-04-1784 ?$ \\
\hline Ballesteros & Miguel & Bs.As. $\quad 24-07-1784$ \\
\hline Bona & Joaquín & Bs.As. $\quad 13-09-1784$ \\
\hline Navarro & Fernando & Bs.As. $\quad 08-02-1785$ \\
\hline Calleja & Marcelino & Bs.As. $\quad 27-04-1785$ \\
\hline Rezábal & Ignacio & Bs.As. $\quad 30-04-1785$ \\
\hline Guido & Pedro & Bs.As. $\quad 10-05-1785$ \\
\hline Sáenz Hermúa & Manuel & Bs.As. $\quad 11-06-1785$ \\
\hline Grandoli & Martín & Bs.As. $\quad 20-08-1785$ \\
\hline Palomeque & Tomás I. & Bs.As. $\quad 14-09-1785$ \\
\hline Sáinz de Cavia & Gregorio & Bs.As. $\quad 16-09-1785$ \\
\hline Pajes & Antonio & Bs.As. $\quad 28-09-1785$ \\
\hline Ibarrola & Juan T. & Bs.As. $21-11-1785$ \\
\hline Serna y Villa & Juan & Bs.As. $\quad 06-12-1785$ \\
\hline Suárez & Nicolás & $15-04-1786$ \\
\hline Núñez & Juan José & $26-05-1786$ \\
\hline Román y Baquero & Manuel & Bs.As. $\quad 08-05-1786$ \\
\hline Basualdo & Manuel & $24-06-1786$ \\
\hline Llobregat & José de & $20-08-1786$ \\
\hline
\end{tabular}

Fuente: Familysearch.org. Cómputos personales tomados de la Iglesia de La Merced entre febrero de 1784 hasta agosto de 1786 ordenados por fecha y del Manuscrito "Noticias sobre casamientos secretos".

Y en la Parroquia de Montserrat, es válido otro ejemplo desde que se contabilizaron 134 matrimonios correspondiendo 57 de ellos a nupcias de conciencia u ocultas $(42,54 \%)$.

Sin duda la conducta de la Iglesia Católica en este breve periodo coincide con las dispensas de proclamas y nupcias ocultas o de conciencia otorgadas a los fieles cuando estos tenían problemas de efectuarlas, por las variadas razones expuestas a lo largo de este trabajo: legislación de la monarquía en vinculación a los civiles (Real Pragmática sobre los hijos de familia y posteriores anexos) y la legislación correspondiente al fuero militar de igual tiempo.

\section{CASUÍSTICA EN BUENOS AIRES. MATRIMONIOS DE CONCIENCIA U OCULTOS DE FUNCIONARIOS, MILITARES, VIUDAS, COMERCIANTES Y OTROS POBLADORES}

Se ha dicho que el desacato a las leyes militares en vigencia ocasionó a los desobedientes varios sinsabores. Los que poseían relaciones políticas o sociales importantes 
en la sociedad, fueran funcionarios o eclesiásticos de rango ${ }^{72}$, se valieron de sus parientes o conexiones para conseguir los indultos. Consta que los oficiales del ejército podían quedar cesantes del cargo, y sus cónyuges al enviudar no gozaban del montepío militar, con los consiguientes problemas económicos para ellas y sus hijos.

Entre los casamientos secretos, aparece el de doña Juana María Tirado, viuda del alférez de dragones don José Gallén. Ella se casó en segundas nupcias con un destacado comerciante bilbaíno el 20 de junio de 1762, en la Iglesia de la Merced, don Nicolás de Acha (hijo legítimo de Domingo Acha y de doña Lucía de Avendaño), ambos nacidos en el mismo Bilbao. Acha era un sólido comerciante matriculado en la Universidad de Cargadores a Indias anotado en 1758 que pasó, en mérito al giro de sus negocios, a Buenos Aires ${ }^{73}$. Por su lado, la novia era nacida en el territorio de San Juan (hija legítima del capitán Juan Tirado y de doña María Fernández de Castro). Se dijo que la contrayente era viuda de don José Gallen -con quien había casado también privadamente en Buenos Aires el 22 de diciembre de 1749. Aquí es más que interesante el dato de que el anterior esposo era de la oficialidad de los dragones de Buenos Aires [a su vez viudo en Buenos Aires de doña Lucía Fernández de Agüero]. El ministro don Domingo Bozzo tomó el consentimiento privadamente a Acha y a Tirado, con dispensas de las tres amonestaciones por el señor Provisor eclesiástico. Los testigos fueron los vecinos porteños don Saturnino Saraza y doña Juana Josefa Tirado, su cuñado y su hermana. Es de agregar, como una característica habitual de este tipo de matrimonio -no excluyente de otros- que la pareja desposada Acha - Tirado y/o sus sucesores solicitaron más tarde copia el 20 de agosto de 1795 a la Curia eclesiástica del vínculo contraído en $1762^{74}$.

Dos desposorios secretos más alumbran la cuestión de la formación de familias en este tipo de nupcias, así las del alférez de dragones don Manuel de Garayo, nacido en Villanubla, obispado de Valladolid, con su novia doña Francisca Antonia Cerrato (hija legítima del capitán don Alonso Cerrato y doña Josefa Pérez), el 24 de junio de 1764. Notables son los agregados -en los renglones siguientes- de la partida matrimonial, con letra y tinta distintas en donde se aclara que se los veló el 22 de julio de 1778. Y, al margen: "Saqué copia a 4 de febrero de 1786", adoptando las características y formas de adecuación canónica de casamiento secreto analizados en este estudio ${ }^{75}$.

De igual forma en este año, el concertado entre el Teniente de dragones de la Compañía de don José Ignacio Quintana, don Manuel de la Rubia, nacido en Villaviciosa, Arzobispado de Toledo quien casó "privadamente" y "con licencia particular", con la dispensa de las tres admoniciones, con doña Teodora Leyva natural de Buenos Aires,

72 Fernández PÉrez, 1997, p. 96, expresa: "Un pariente en el obispado o en la parroquia correspondiente permitía lograr con rapidez las dispensas precisas y el secreto deseado. Los libros de matrimonios parroquiales muestran cómo a menudo el sacerdote que bendecía el matrimonio secreto era un pariente de los desposados".

73 Ruiz, 1988, p. 13.

74 JÁUREGUI, 1989, p. 16. La partida Gallén - Tirado expresa que -además- se dispensó el impedimento en cuarto grado de afinidad.

75 Una hija, María Josefa, fue bautizada en su carácter de hija legítima en la Parroquia de La Merced el 3 de junio de 1769. En las digitalizaciones de IJSUD, search.org. no aparece el matrimonio de los padres. 
el 14 de octubre de 1764. Aquí también en el margen existe la frase: "Saque copia a 29 de [?] 1791" 76.

Por lo demás, en el Libro de matrimonios de esta misma Iglesia de La Merced consta un enlace celebrado en 1772, que no siguió la normativa de las proclamas comunes, y se destaca que fue privado. En efecto, se corrió la primera monición el día 5 de abril de ese año en momentos de la misa mayor de los que deseaban casar, el Teniente de dragones Manuel Gutiérrez del obispado de Osma (hijo legítimo del Coronel de infantería don José Gutiérrez y de Bernarda Varona), y doña Ana María Mendinueta (hija legítima del capitán de dragones y maestre de campo don Lázaro Bernardo Mendinueta y de doña Bartola Gayoso y Aldunate). Sobre las dos restantes moniciones se asentó: “... por especial orden del Ilmo. Sr. Obispo corridas el mismo día las otras dos en las misas de once y doce (...), casó privadamente el referido doctor en mi semana y con mi anuencia ..." 77 .

Un conflicto entre el capitán del cuerpo de artillería don Francisco Orduña y el virrey Loreto -en nombre de S.M.C.- en el año 1786 por no haberle concedido la licencia para casarse con doña María Juana Carballo, demuestra que hubo situaciones de orden privado que involucraron la participación directa de la Iglesia para su concreción $^{78}$.

En orden a estos hechos buen disgusto recibió don Pedro de Arce cuando señaló que se le había expedido venia militar para casarse con doña Martina Lavardén pero el mismo virrey le colocó obstáculos para realizar sus deseos ${ }^{79}$. Lo cierto es que Loreto que gobernaba en Buenos Aires tenía serias dudas de que estos matrimonios ya se hubieran efectuado de forma secreta.

Además de la mención de los casamientos citados, aparecen en los libros de las partidas matrimoniales de la Iglesia de la Merced las nupcias secretas de don Miguel García, "Teniente de infantería y Capitán de este puerto" (dato éste que surge de la partida de bautismo de una de sus hijas), viudo de doña Gertrudis Guestardo en Cartagena del Levante, Murcia, con doña María Eusebia Martínez Fontes (hija legítima del gobernador del Paraguay -difunto- don José Martínez Fontes y de doña Josefa Bustamante). En este caso, el provisor y vicario general, D. Miguel de Andújar de Buenos Aires dio licencia para casarlos privadamente, en su casa, al Arcediano D. Miguel José de Riglos. Les fueron dispensadas las tres proclamas el 28 de abril de 1778 en donde se agregó: "del año pasado". Es decir que se asentó una partida anterior a las que corrían en el libro de la parroquia de La Merced en donde se estaban escribiendo -además- las de 1779 . Se anotó en estos párrafos, haber sido la contra-

76 El matrimonio bautizó una hija, Manuela Cayetana, como hija legítima: IJSDU, Argentina, Capital Federal, Nuestra Señora de La Merced, registros parroquiales, bautismos, 1737-1977, 8 de agosto de 1765; imagen 372 de 666.

77 El matrimonio Gutiérrez - Mendinueta no se encuentra registrado en las bases de datos digitalizadas de matrimonios de Buenos Aires, tampoco hijo alguno.

78 Francisco de Orduña y María Juana Carvallo, para levantar la prohibición sobre la licencia real concedida. AGS, Secretaría de Estado y del Despacho de Guerra, leg. 7223, 36. 1789. E1 28 de agosto de 1802 anotaron una hija legítima en la Iglesia de La Merced: María Josefa Luiza: IJSUD, Argentina, Capital Federal, registros parroquiales, Bautismos, 1801-1811, imagen 73 de 780. El matrimonio de los padres no consta.

79 Fernández De Burzaco, 1990, V. Este matrimonio no figura en los Padrones Biogenealógicos de Buenos Aires. 
yente viuda en Buenos Aires, del militar teniente coronel don Domingo Bursua ${ }^{80}$. Sus testigos fueron don Francisco Rodrigo, Capitán de infantería del regimiento de "este presidio" y don Andrés Cantabrana. En el margen se agregó que se sacó copia -una vez más en este tipo de casamiento- el 3 de julio de $1790^{81}$.

A su vez, pudo consultarse parte de la documentación del capitán del cuerpo de dragones don Vicente de Carballo y Goyeneche, nacido en Valdivia en 1742 que murió en Buenos Aires en 1816, autor de una importante descripción del Reino de Chile. Se conoce que había "casádose clandestinamente" (sic). En ocasiones, se consideró su casamiento secreto como clandestino, a pesar de las disposiciones del Concilio de Trento, pero se deja ver a todas luces que fue un casamiento secreto. Si bien esa situación se reconocía como un delito, el rey lo indultó por su destacada acción en el desempeño de sus funciones, con fecha 10 de diciembre de $1793^{82}$.

En las figuras relevantes, también pudo constatarse el enlace secreto del capitán de dragones, don Francisco Bruno de Zavala, quien fuera hijo del gobernador don Bruno Mauricio de Zavala (1682 +1736), con doña Josefa Cecilia García de la Paz, de la que no constan datos. Obsérvese la anotación que el Dr. Don Juan Cayetano Fernández de Agüero -cura rector- colocó en el libro de matrimonios de la Parroquia de La Merced: "Por no haberse hallado la partida del casamiento y velación del capitán don Francisco Bruno de Zavala le di copia certificada de la abreviada en el libro de colecturía. Hoy 5 de agosto de 1779".

\section{Figura 1}

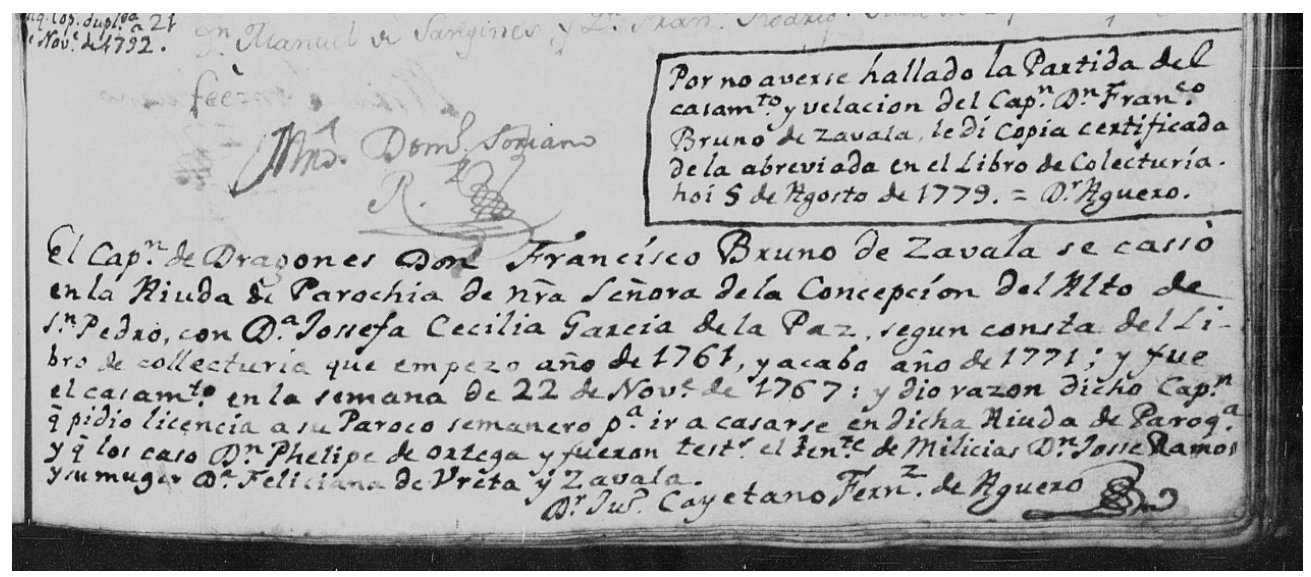

Fuente: IJSUD, Argentina, registros parroquiales, 1737-1977, ciudad de Buenos Aires, Nuestra Señora de La Merced, Matrimonios 1760-1808, I: 70.

80 IJSUD, Argentina, registros parroquiales, 1737-1977. Ciudad de Buenos Aires, Nuestra Señora de La Merced, Matrimonios 1760-1808, I, 138.

81 Ibídem, no se encuentra la partida de matrimonio. Anotaron como hijo legítimo a José Bautista, en los bautismos de la Parroquia de La Merced, el 20 de octubre de 1783.

82 Búsqueda del capitán de Dragones de la Frontera de Chile D. Vicente de Carballo, acusado de desobediencia y matrimonio clandestino. AGS, Delitos, leg. 6807, 34, Fol. 453I. Asimismo, cfr.: Briceño, 1862, p. 525 . 
Se destaca que el rey mencionó a don Francisco Bruno como teniente coronel de dragones de Buenos Aires (en este cargo desde septiembre de 1787), quien poseía el cargo de Gobernador de los treinta pueblos orientales. En cartas al Monarca el último solicitó un empleo en la zona de su residencia ${ }^{83}$. Cabe la pregunta, no menor en este tema como para otros destacados funcionarios de la Corona en Indias, si el que fue el gobernador de Montevideo, don Bruno Mauricio de Zavala haya tenido asimismo, en su tiempo, un matrimonio secreto ya que no se ha podido encontrar su partida ¿qué ocurría si el rey se enteraba de un casamiento de esta condición expresamente prohibido, llevado a cabo por el que tenía a su cargo un sector de la administración político-militar de la Monarquía en Indias? ¿Cuál podía ser la reacción del soberano ante la política de un matrimonio secreto de uno de sus principales representantes en Indias con una dama del lugar?

El primer hijo de don Bruno Mauricio de Zavala fue bautizado el 10 de octubre de 1719, en épocas tempranas, de 5 días; de Francisco Bruno no se tienen datos; Luis Aurelio lo fue el 23 de enero de 1722 y de José Ignacio, nombrado en 1761 teniente de dragones del Real Presidio, no figura su bautismo ${ }^{84}$, tampoco consta el nombre de quien los dio a luz. Tiempo más tarde, aquél don Luis Aurelio ${ }^{85}$, se casó con doña Pascuala Josefa de la Torre. En su tiempo este nuevo matrimonio, tuvieron una hija, doña Josefa Antonia Zavala, quien casó con don Pedro José de la Cuadra, "Teniente de milicias de infantería", nacido en Álava. Pudo conocerse que los últimos contrajeron enlace el 3 de noviembre de 1763, con licencia del provisor general del Obispado Dr. Don Miguel José de Riglos otorgada al Rvdo. P. lector don José Gil -en el oratorio sagrado- (por lo general estaba prohibido) que tenía el propio Don Luis Aurelio de Zavala en su quinta, cuyo lugar no se insinuó. Recién en momentos de la velación de los casados, de acuerdo a la partida de La Merced, se expresó que se concedía permiso especial para la misma el 24 de abril de 1780, es decir, 13 años después. En resumidas cuentas, la velación venía a atestiguar un matrimonio secreto, siendo éste anotado -entonces- con la última de las fechas, y bajo palabra que le dio el propio don Luis Aurelio de lo ocurrido con su hija y su yerno al encargado eclesiástico Dr. D. Fernández de Agüero. Cabe expresar que la partida de casamiento no figuraba en los libros comunes sacramentales.

En estas circunstancias se señaló que el padre de la novia era una persona de gran distinción y que tanto él como su esposa habían sido testigos de su casamiento y en la velación apuntada. Para todo ello se consignó la firma -que refrendaba la inclusión de las partidas- del Dr. don Cayetano Fernández de Agüero, como cura rector propietario.

Amén de estas anotaciones el matrimonio Cuadra - Zavala bautizó a su vez en el siglo a una de sus hijas el 12 de octubre de 1763 -recuérdese que parecía que la pareja

83 Solicitud de nombramiento para algún gobierno que hace D. Francisco Bruno de Zavala, teniente coronel de Dragones de Buenos Aires. AGS, Secretaría de Estado y Despacho de Guerra, leg. 6803, 22, folios $140-143$.

84 Fernández de Burzaco, 1991, VI, p. 313.

85 IJSUD, Argentina, registros parroquiales, 1737-1977, ciudad de Buenos Aires, Nuestra Señora de La Merced, Matrimonios 1747-1796, I: 167. 
había matrimoniado según consta en los Padrones de Burzaco ${ }^{86}$, el 3 de noviembre de 1763-; y durante los siguientes 22 años engendraron más hijos. Fuera por motivos de que las partidas no aparecían, o porque se trató de matrimonios secretos, lo cierto es que durante el siglo XVIII cuatro conocidos personajes de la sociedad rioplatense, de una misma familia, contrajeron nupcias de forma secreta: don Bruno Mauricio de Zavala, y sus hijos don Francisco Bruno y don Luis Aurelio de Zavala, y una hija de éste, doña Josefa Antonia que consolidó las nupcias: Cuadra - Zavala.

No menos interesantes resultan dos casos de 1774 relacionados con el espacio del entorno cuyano del virreinato del Río de la Plata. El de Carlos Spano [Espano], nacido en Málaga, teniente del regimiento de la Concepción de Chile que matrimonió secretamente en Mendoza con María de las Nieves Cevallos el día 26 de febrero de 1797 en la Iglesia San Nicolás de Tolentino de Mendoza. Otro tanto ocurrió a continuación -de acuerdo con la partida matrimonial del día inmediatamente siguiente 27 de febrero- en idéntica parroquia con el teniente de dragones Manuel Vial y Cardigondi, de Buenos Aires (su padre había sido teniente coronel, nacido en Bilbao), el que tuvo enlace con la hermana de la anterior: Martina Cevallos. Uno y otro con un día de diferencia salieron como testigos del matrimonio secreto de su camarada de armas. $\mathrm{Al}$ respecto se dijo:

Ambrosio José de Ochoa -párroco en esa ciudad de Cuyo-, decía que, constándole la nobleza de las dos mujeres, se atenía al mandato de la Iglesia de celebrar los matrimonios ante causas de honor graves, como era el $\mathrm{caso}^{87}$.

Cabe indicar que ambos oficiales obtuvieron finalmente la licencia militar del rey según surge de la constancia emitida para "tropa de Chile" de 1798. Esto se efectuó luego de que tanto uno como otro oficial habían sido separados del cuerpo militar con suspensión de sus sueldos ${ }^{88}$. Con las licencias obtenidas pudieron recobrar sus grados, y las pagas respectivas.

Y si vuelve a retroceder en el tiempo, siempre en cuanto a lo acaecido con los cuerpos militares del ejército, el 14 de julio de 1773 casaron privadamente el capitán del regimiento de dragones don Juan Somaló (compañero de armas del futuro jefe de la independencia General don José de San Martín), con doña Ana Arroyo y González, “... a quienes el metropolitano de Charcas dispensó las tres proclamas" y el impedimento que tenían los contrayentes de primer grado de afinidad en línea transversal nacida en "cópula lícita" ${ }^{89}$. El 26 de marzo de 1774 el matrimonio anotó a una hija, María Manuela Josefa de la Encarnación, nacimiento en el que figura como legítima ${ }^{90}$, al igual que los siguientes hermanos. En su juventud, doña María Manuela Josefa contrajo enlace con don Félix Iriarte "privadamente", capitán del

\footnotetext{
86 Fernández de Burzaco, 1987, II, p. 179.

87 Indultos concedidos a los tenientes Carlos Espano y Manuel Vial por haberse casado sin licencia, posesionándoles en sus mismos empleos. Remite para resto del Expediente a Tropa de Chile. IV-1798. AGS, Secretaría de Estado y del Despacho de Guerra, leg. 7231, 48.

88 Ibídem.

89 IJSUD, Argentina, registros parroquiales, 1737-1977. Ciudad de Buenos Aires, Nuestra Señora de La Merced, Matrimonios 1760-1808, I, 111.

90 Ibídem, Iglesia Parroquial Nuestra Señora de la Merced, 22-III-1774. Libro de Bautismos.
} 
regimiento de infantería, natural de Gerona, Cataluña, el 9 de mayo de 1782, con dispensa de dos proclamas, mediante poder dado al teniente coronel don Benito Vial $^{91}$.

En otro caso más, hubo dispensas de las tres moniciones y las nupcias se realizaron reservadamente en una casa de la que no se menciona su propietario. Esto tuvo lugar en ocasión del enlace cumplido el 8 de febrero de 1785 cuando se dio licencia "provisoral" (mientras esperaban la licencia respectiva), por "graves y justos motivos" a don Fernando Navarro, nacido en Madrid, capitán del cuerpo de dragones "de esta frontera", con doña Margarita Fernández (hija del teniente Manuel Fernández y de Antonia Pérez). El matrimonio fue velado en el mes de noviembre de igual año, sacándose copia de la partida diez años después, en noviembre de 1795.

Varios descendientes de personas que casaron en secreto, han buscado las partidas de sus antepasados sin hallarlas. Es el caso del casamiento que se consideró clandestino cuando, en realidad -a todas luces-, fue secreto ${ }^{92}$. Se ha podido leer la licencia solicitada al rey en un Memorial por don Luis Lafinur, alférez de dragones de Buenos Aires para casar con doña María Bibiana Pinedo, fechado el 4 de diciembre de 1794. Es de aclarar que la solicitud no se inició en esta fecha ya que hay notas desde el 2 de enero de $1793^{93}$. En su Memorial expresó: a) no tenía su fe de bautismo, y le llevaría tiempo solicitarla a Pamplona donde había nacido; b) no tenía el consentimiento paterno (tampoco lo necesitaba por su edad de 41 años), aparte que declaró que sus padres habían muerto (si bien se le exigió las "fees de muertes" correspondientes); c) la novia tenía el consentimiento para recibir el sacramento nupcial de sus padres. En este sentido el Consejo de Guerra opinó que la dote de la novia de $\$ 3.000$-por nota del 31 de julio de 1795 - debía integrarse siendo depositada en debida forma.

A lo largo del Memorial de don Luis Lafinur surge que en la familia materna (la madre de doña María Viviana Pinedo era doña Petrona Montenegro) había otros militares. Sobre la novia se adujo que tampoco se podía encontrarse la partida de bautismo. Los testigos declararon su testimonio jurando: "bajo su palabra de honor puesta la mano derecha sobre la cruz de su espada" 94 . Es decir una familia con un entorno militar, a la vez que se expresa: "Según tradicional oral no confirmada Lafinur era hijo de otro oficial de igual nombre y apellido, capitán en el real regimiento de Berga" ${ }^{95}$. De hecho el petitorio de don Luis Lafinur sería aceptado siempre y cuando cumpliera los requisitos exigidos, recordando detalles de importancia con respecto al Montepío militar, tema que excede este apartado. En estas circunstancias, en 1796, doña Walda de Sosa, vecina de la Carolina, los denunció por considerar que estaba en presencia de un casamiento clandestino y por considerarlo su

91 Ibídem, Argentina, registros parroquiales, 1737-1977. Ciudad de Buenos Aires, Nuestra Señora de La Merced, Matrimonios 1747-1796, I, 172. Fernández De Burzaco, 1991, VI, p. 63. Estos Padrones de familias la mencionan solamente como hija, sin aclarar su legitimidad, de don Juan Francisco de Villoslada y Somaló -así sus apellidos completos- y de doña Ana María de Arroyo.

92 TORRe, 2013, pp. 575-592.

93 Ibídem, p. 581.

94 Ibídem, p. 587. Información del testigo don Rafael de León, entre otros militares, Regidor de la Ciudad de Córdoba y Capitán de milicias.

95 Ibídem, p. 574. 
deber en la época, de acuerdo a los preceptos católicos. De hecho, todavía a fines del siglo XVIII, se repetía el desconocimiento de lo establecido en el Concilio de Trento que podía llegar hasta excomulgar a quienes habían participado en un enlace de ese tipo. Pero se comprende que las nupcias de Lafinur no fueron clandestinas ya que se trató, una vez más, de bodas secretas, del tipo de las que se expusieron anteriormente.

Sólo resta evocar los nombres de otros pobladores, funcionarios en Indias durante el siglo XVIII que enlazaron secretamente. Además del oidor D. Tomás Ignacio de Palomeque; el comerciante y por momentos destacado empleado de la Monarquía D. Manuel Gallegos y Valcárcel ${ }^{96}$, el secretario del Reino D. Juan Justo Marchan y García, el administrador de la Aduana D. Francisco Jiménez de Mesa, las nupcias de D. Martín José de Altolaguirre, a la sazón oficial de la Real Hacienda, por mencionar parte de los que se conocen.

En síntesis, si bien es imposible hacer referencia a todos los casamientos secretos sobre los que se posee otros numerosos ejemplos, se estima que los expuestos constituyen una válida muestra de exposición de los realizados en Buenos Aires y en el resto de los territorios del Antiguo Régimen durante la centuria del dieciocho.

\section{CONCLUSIONES}

Se hizo alusión a diferentes matrimonios secretos durante el siglo XVIII, destacándose la parte activa que tuvo don Miguel José de Riglos como provisor a cargo del Obispado en la concertación de estos desposorios en Buenos Aires, con la ayuda del Maestre Dr. Juan Baltazar Maciel.

Asimismo, se pudo constatar la gran cantidad de nupcias ocultas o de conciencia llevadas a cabo en otros territorios de Hispanoamérica. En todos los ejemplos se alcanzó a observar la competencia existente entre la Iglesia y la Monarquía por el poder temporal. El objetivo no ha sido analizar casos peculiares, sino los que surgieron del contexto generalizado ocurrido en el Río de la Plata.

A pesar del manejo del Patronato Real por España, fue permanente la intervención de la Iglesia Católica a favor de sus feligreses y la salvación de sus almas cuando se consideró que no había otras alternativas que los alejara del pecado y consiguientes concubinatos.

De manera que los matrimonios secretos citados a lo largo de este estudio, encuentran un aporte en los formalizados por oficiales de las fuerzas militares. Para ello, fue necesario indagar en una amplia bibliografía que implica conocer sobre las licencias, indultos y montepío militar del tiempo en cuestión, y su aplicación en Hispanoamérica. No obstante, fue la indagación del Derecho Canónico, aplicado a la observación de las partidas matrimoniales y la casuística ocurrida en Buenos Aires y en otros ámbitos Hispanoamericanos, lo que llevó a desentrañar situaciones en un material documental extremadamente rico de fuentes, vinculado a diferentes sucesos privados, entre otros, los relacionados con los funcionarios de la corona,

96 SENOR, 2005; SiEgrist, 2014, pp. 27-29. 
que no podían contraer enlace en el lugar de su residencia, las personas de diferente religión, los comerciantes matriculados en la Universidad de Cargadores a Indias en Cádiz arribados al Río de la Plata, las viudas, las personas ordenadas en religión, los concubinos de larga data con hijos de por medio (o sin ellos), los españoles que optaron por casar con esclavas, etc.

Las digitalizaciones que hoy existen de los documentos pertinentes, mencionadas a lo largo de este estudio, tales como las partidas sacramentales de parroquias de la Iglesia de La Merced de Buenos Aires entre los años 1760 hasta 1800, otras del espacio americano y fuentes subidas a la consulta general en internet por diferentes instituciones internacionales nacionales y privadas citadas a lo largo de la exposición, ampliaron las consideraciones que se efectúan. A pesar de ello, aún no ha sido posible obtener porcentajes de los casamientos secretos, ocultos o de conciencia, debido a que se deberían revisar fuentes en un marco de varios miles de documentos.

En el presente trabajo surgieron las condiciones que tuvieron las ceremonias secretas en su concreción: dispensa de las tres proclamas, in facie eclessiae, la presencia del sacerdote con el consentimiento de los novios por palabras de presente y no de futuro, el juramento de mantener los desposorios en un ámbito hermético y privado, la participación de dos testigos por lo general los padres, que debían prometer mantener igual impenetrable verdad en incógnito, la licencia in scriptis otorgada por el Obispo al párroco o prelado que casaba a los contrayentes. Otro hecho que delata este tipo de nupcias, fue que se realizaron en casas de morada u oratorios privados, y en horarios no usuales. Deben sumarse los juramentos para que, en caso de que existiese prole ya concebida o por venir, la educaran en la doctrina cristiana, salvaguardando su crianza y futuro, debiendo dar cuenta de su nacimiento antes de los 30 días de nacidas. Las personas con ese tipo de casamientos, cuando obtuvieron las licencias perseguidas, pidieron su anotación en los libros comunes de matrimonios, si bien no todos lo lograron. También se pidieron copias de los nacimientos de los hijos o de los mismos casamientos una vez aclarados estos en su real existencia, de acuerdo a lo que figura -por lo general- en los márgenes de los mismos libros parroquiales. Los expedientes matrimoniales en este tipo de desposorios, siempre aparecieron con las palabras "Urgente", "Urgentísimo", "Grave".

Se buscó realizar un trabajo general sobre casamientos secretos en el Río de la Plata y no solo los aislados. Cabe acotar que, los matrimonios de este tipo en Hispanoamérica, han sido a la fecha estudiados desde este punto de vista, es decir, como hechos aislados, salvo casos de comerciantes en su conjunto.

Una pequeña muestra de aproximadamente tres años realizada en la Iglesia de la Merced se destaca, desde que existe una "Noticia de casamientos secretos" puntual con alusión al lapso 1784-1786 en Buenos Aires, llevó a considerar que sobre 137 nupcias corrientes efectuadas en ese tiempo en la Iglesia de la Merced (Catedral de Buenos Aires), 19 se concretaron como matrimonios de ese tipo (13,9\%). A su vez, en la Parroquia de Monserrat existieron en igual periodo 134 matrimonios y 57 de ellos fueron secretos (42.54\%). Ello lleva a considerar que el 56,54\% de las nupcias en esas dos Iglesias tuvieron la dispensa de proclamas, cantidad destacable si se consideran los años analizados. 
No se han calculado aún las que se corresponden con otras Iglesias en la ciudad porteña del periodo hispánico (San Nicolás, Nuestra Señora de la Inmaculada Concepción, Nuestra Señora de la Piedad, Nuestra Señora del Socorro y la que se menciona como ayuda de parroquia "Alto de San Pedro").

A pesar de ello, las causas que motivaron ceremonias sacramentales secretas no siempre desaparecieron como, por ejemplo, cuando se trató de nupcias de personas con notoria diferencia de linaje, circunstancias manifestadas con toda nitidez de las disposiciones del papa Benedicto XIV, en su Encíclica Satis Vobis Compertum de $1741^{97}$.

\section{REFERENCIAS BIBLIOGRÁFICAS}

Aguirre, Severo

1794 Prontuario alfabético y cronológico por Orden de materias, de las Instrucciones, Ordenanzas, Reglamentos, Pragmáticas y demás Reales resoluciones no recopiladas, que han de observarse para la administración de la justicia y gobierno de los pueblos del Reyno. Madrid, 2a. Impresión.

Arroyo Zapatero, Luis - Blázquez, María (coords.)

1999 “Introducción”. En ZAHINo, El cardenal Lorenzana y el IV Concilio Provincial Mexicano. México. Universidad Nacional Autónoma de México - Miguel Ángel Porrúa - Universidad de Castilla La Mancha - Cortes de Castilla La Mancha.

Balduque Marcos, Luis Miguel

2002 El Ejército de Carlos III: Extracción social, origen geográfico y formas de vida de los Oficiales de S. M. Madrid. Universidad Complutense de Madrid (Tesis doctoral). En http://eprints.ucm.es/2363/1/AH0016401.pdf

BEVERINA, Juan

1992 El Virreinato de las provincias del Río de la Plata, su organización militar: contribución a la Historia del ejército argentino. Buenos Aires. Biblioteca del Oficial, $2^{\circ}$ ed.

BRICEÑO, Ramón

1862 Estadística bibliográfica de la literatura chilena. Santiago de Chile. Consejo de la Universidad de Chile.

Bunge, Alejandro, Pbro. Dr.

2007 Iglesias particulares II. Buenos Aires, s.e. (Materia dictada en Facultad de Derecho Canónico, Pontificia Universidad Católica Argentina). En http://www.awbunge. com.ar/Igparticulares2-U2.pdf

Colección

1790 Colección en latín y castellano de las Bulas, Constituciones, Encyclicas, Breves y Decretos del Santísimo Padre (de gloriosa memoria) Benedicto XIV. Hecha según la auténtica Edición Romana del Bulario del mismo Pontífice, de 1760. Madrid. Oficina de D. Antonio Espinosa.

Colón De Larreátegui Jiménez De Embún, Félix.

1828 Juzgados militares de España y sus Indias. París, II.

97 SIEGRIST, 2014. 
Chacón Jiménez, Francisco - Bestard, Joan (dirs.)

2011 Familias de la sociedad española (del final de la Edad Media a nuestros días). Madrid. Cátedra.

Chacón Jiménez, Francisco - Méndez VÁzquez, Josefina

2007 "Miradas sobre el matrimonio en la España del último tercio del siglo XVIII". Cuadernos de Historia Moderna. Madrid, n 32, pp. 61-85.

DíEz Martín, María Teresa

2008 "Representaciones y prácticas de género en la proyección del colectivo social de la oficialidad militar. Una estrategia de la política colonial en el siglo XVIII". Revista Destiempos. México D.F., nº 14, pp. 354-396.

Donoso, Justo P.

1861 Instituciones de Derecho Canónico Americano, para el uso de los Colegios de la América Española. Santiago de Chile. Imprenta Nacional, $2^{\circ}$ ed., 2 tomos.

Dougnac Rodríguez, Antonio

2003 Esquema del Derecho de Familia Indiano. Santiago de Chile. Instituto de Historia del Derecho Juan de Solórzano y Pereyra. En http://www.larramendi.es/i18n/catalogo_imagenes/grupo.cmd?path $=1000175$

FALCón Gómez SÁNCHEZ, Francisco José

2007 "El matrimonio clandestino de María Isabel Cavero. Conflicto entre amor, leyes e Iglesia, en Truxillo del Perú, a fines del siglo XVIII (1794)". Nuevo Mundo Mundos Nuevos, Debates, $n^{\circ} 7$. En https://nuevomundo.revues.org/3352

Fernández de Burzaco, Hugo

1986-91 Aportes Biogenealógicos para un Padrón de Habitantes del Río de la Plata. Buenos Aires. R.J. Pellegrini e Hijo, Impresiones, 6 vol.

FERnández PÉREZ, Paloma

1997 El rostro familiar de la Metrópoli. Redes de parentesco y lazos mercantiles en Cádiz, 1700-1812. Madrid. Siglo XXI España Editores.

FERRER ORTIZ, Javier

1997 “Celebración del matrimonio en secreto e inscripción en el registro civil”. Ius Canonicum. Pamplona, $\mathrm{n}^{\circ}$ XXXVII, pp. 151-186.

FRADKIN, Raúl

2014 "Las milicias de caballería de Buenos Aires, 1752-1805". Fronteras de la Historia. Bogotá, n 19, pp. 124-150.

GarcíA-AbÁsolo GonzÁlez, Antonio

2008 "Formas de alteración social en Filipinas. Manila, escenario urbano de dramas personales”. En LuQue Talaván - Manchado López, Un Océano de intercambios, I. Madrid. Ministerio de Asuntos Exteriores, pp. 255- 284.

Ghirardi, Mónica - Irigoyen López, Antonio

2009 "El Matrimonio, el Concilio de Trento e Hispanoamérica". Revista de Indias. Madrid, $n^{\circ} 246$, pp. 241-272.

GiL MuÑoz, Margarita

2004 "Aproximación al estudio de la vida familiar de los militares españoles (siglo XVIII")". Revista de Historia Militar. Madrid, n 96, pp. 99-146.

Golmayo, Pedro Benito

1999 Instituciones del Derecho canónico por el doctor Pedro Benito Golmayo [Madrid. Librería de Gabriel Sánchez, 1896]. Alicante. Biblioteca de la Universidad 
de Alicante. En http://www.cervantesvirtual.com/obra/instituciones-del-derechocanonico-0/

JÁuREgui RuedA, Carlos

1989 Matrimonios de la Catedral de Buenos Aires, 1747-1823. Buenos Aires. Fuentes Históricas y Genealógicas Argentinas.

KONETZKe, Richard

1962 Colección de documentos para la historia de la formación social de Hispanoamérica. 1493-1810. Madrid. Consejo Superior de Investigaciones Científicas, Vol. III.

Pastora y Nieto, Isidro de la

1848 Traducción del Diccionario de Derecho Canónico, traducido del que ha escrito en francés el Abaté Andrés, Canónigo honorario, miembro de la Real Sociedad asiática de París..., III. Madrid. José de la Peña Editor. En http://fama2.us.es/fde/ ocr/2010/diccionarioDeDerechoCanonicoT3.pdf

Pico, José María

1989 “Introducción”. En JÁuregui, Matrimonios de la Catedral de Buenos Aires, 17471823. Buenos Aires. Fuentes Históricas y Genealógicas Argentinas, pp. 5-9.

1991 "Don Guillermo Ross. Un escocés altanero". Genealogía. Revista del Instituto Argentino de Ciencias genealógicas. Buenos Aires, nº 24, pp. 167-202.

Quinteros, Guillermo O.

2010 Ser, sentir, actuar, pensar e imaginar en torno al matrimonio y la familia: Buenos Aires, 1776-1860. La Plata. Universidad Nacional de La Plata. Facultad de Humanidades y Ciencias de la Educación (Tesis de posgrado). En http://www.memoria. fahce.unlp.edu.ar/tesis/te.446/te.446.pdf

RíPodas Ardanaz, Daisy

1977 El Matrimonio en Indias. Realidad social y regulación jurídica. Buenos Aires. FECIC.

R[odríguez] O.R. De Soaje Pinto, Esther

1999 Matrimonios de la Parroquia del Socorro, 1783-1869. Buenos Aires. Instituto Argentino de Ciencias Genealógicas.

Ruiz Rivera, Julián B.

1988 El Consulado de Cádiz. Matrícula de comerciantes, 1730-1823. Cádiz. Diputación Provincial de Cádiz.

SENor, María Selva

2005 “"El azar y la necesidad'. Elite y elecciones matrimoniales en Buenos Aires 17761820: Las familias Azcuénaga y Andonaegui”. Revista Andes. Salta, no 16, pp. 201221. En http://editorial.unsa.edu.ar/ojs/index.php/Andes/article/viewFile/148/136

SIEGRIST, Nora

2014 "Dispensas y libros secretos de matrimonios en la segunda mitad del siglo XVIII y la primera del XIX en actuales territorios argentinos”. HiSTOReLo. Revista de Historia Regional y Local. Medellín, vol. 6, n 12, pp. 14-57. En http://www.scielo. org.co/pdf/histo/v6n12/v6n12a02.pdf

2016 Noticia sobre casamientos secretos en la segunda mitad del siglo XVIII. Contribución a la historia de las familias y la genealogía durante el Virreinato del Río de la Plata. Buenos Aires. Instituto Argentino de Ciencias Genealógicas.

Siegrist, Nora - Ferreyra, María del Carmen

2012 "Catálogo de dispensas matrimoniales de Córdoba del Tucumán (y otras provincias de su Obispado): 1809-1842. Fuentes histórico-genealógicas de la conformación de 
la Sociedad Argentina". Revista del Centro de Estudios Genealógicos y Heráldicos de Córdoba. Córdoba, no 40, 52 pp.

SzÁszDI, Adám

1963 "Un episodio en las relaciones entre el estado y la Iglesia bajo el real patronato". Revista del Instituto de Cultura Puertorriqueña. San Juan, nº 6, 18, pp. 13-16.

TORRE, Luis de

2013 “Don Luis Lafinur y la licencia real para casarse”. Genealogía. Revista del Instituto Argentino de Ciencias Genealógicas. Buenos Aires, nº 35, pp. 575-592.

TwINAM, Ann

2009 Vidas públicas, secretos privados, Género, honor, sexualidad e ilegitimidad en la Hispanoamérica colonial. Buenos Aires. Fondo de Cultura Económica de Argentina.

VÁzQuez Cienfuegos, Sigfrido

2007 "Comportamiento de las tropas veteranas en Cuba a principios del siglo XIX". Estudios Americanistas. Sevilla, no 19, pp. 103-109.

ZAHINO PEÑAFORT, Luisa (rec.)

1999 El Cardenal Lorenzana y el IV Concilio Provincial Mexicano. México. UNAM Miguel Ángel Porrúa - Universidad de Castilla La Mancha - Cortes de Castilla La Mancha. 